\title{
CAMA
}

Centre for Applied Macroeconomic Analysis

\section{Regulatory Stress Tests and Bank Responses}

\section{CAMA Working Paper 77/2020 August 2020}

\section{Karel Janda}

Department of Banking and Insurance, University of Economics, Prague Institute of Economic Studies, Charles University

Centre for Applied Macroeconomic Analysis, ANU

\section{Oleg Kravtsov}

Department of Banking and Insurance, University of Economics, Prague

\section{Abstract}

In this paper, we investigate how the regulatory stress test framework in the European Union affects banks' investment decisions and portfolio choices. Using the causal inference and event study methodology, we document a substantial impact of EU-wide stress tests in 2011, 2014 and 2016 on the banks' portfolio strategies. The banks subject to regulatory stress tests tend to structure their portfolios with lower risk assets that is reflected in a decline in risk-weighted assets as compared to the control group. At the same time, the dynamic of realized risk that is measured by the proportion of nonperforming exposure in portfolios remains unaffected. The estimates based on two alternative subsamples indicate that the magnitude of such effect rise with the increase in the size of the bank's assets. 


\section{Keywords}

regulatory stress test, capital regulation, heterogeneous treatment effect, event study, instrumental variable

\section{JEL Classification}

G20, G21, G28

\section{Address for correspondence:}

(E) cama.admin@anu.edu.au

\section{ISSN 2206-0332}

The Centre for Applied Macroeconomic Analysis in the Crawford School of Public Policy has been established to build strong links between professional macroeconomists. It provides a forum for quality macroeconomic research and discussion of policy issues between academia, government and the private sector.

The Crawford School of Public Policy is the Australian National University's public policy school, serving and influencing Australia, Asia and the Pacific through advanced policy research, graduate and executive education, and policy impact. 


\title{
Regulatory Stress Tests and Bank Responses \\ Karel Janda-Oleg Kravtsov*
}

\begin{abstract}
:
In this paper, we investigate how the regulatory stress test framework in the European Union affects banks' investment decisions and portfolio choices. Using the causal inference and event study methodology, we document a substantial impact of EU-wide stress tests in 2011, 2014 and 2016 on the banks' portfolio strategies. The banks subject to regulatory stress tests tend to structure their portfolios with lower risk assets that is reflected in a decline in risk-weighted assets as compared to the control group. At the same time, the dynamic of realized risk that is measured by the proportion of non-performing exposure in portfolios remains unaffected. The estimates based on two alternative subsamples indicate that the magnitude of such effect rise with the increase in the size of the bank's assets.
\end{abstract}

Keywords: regulatory stress test, capital regulation, heterogeneous treatment effect, event study, instrumental variable

JEL classification: G20, G21, G28

* Karel Janda; Department of Banking and Insurance, University of Economics, Prague, W. Churchilla 4, 13067 Praha 3, Czech Republic, Institute of Economic Studies, Charles University, Opletalova 26,11000 Praha 1, Centre for Applied Macroeconomic Analysis (CAMA), Crawford School of Public Policy, ANU College of Asia and the Pacific, J. G. Crawford Building \# 132 Lennox Crossing, Acton ACT 2601 Australia, Email: Karel-Janda@ seznam.cz

Oleg Kravtsov; Department of Banking and Insurance, University of Economics in Prague, Email: krao02@vse.cz

The article is part of a project that has received funding from the European Union's Horizon 2020 Research and Innovation Staff Exchange programme under the Marie Sklodowska-Curie grant agreement No. 681228. We also acknowledge support from the Czech Science Foundation (grant 18-05244S). The views expressed in the paper are those of the authors and not necessarily those of our institutions. 


\section{Introduction}

In the post-crisis period, stress testing has emerged as one of the major tool used by regulators to assess the resilience of individual institutions and financial systems to economic shocks. Since 2010, the Committee of European Banking Supervisors (CEBS) and the European Banking Authority (EBA) have been conducting a European Union (EU)-wide stress tests of the banking system with an aim to assess the resilience of financial institutions to adverse market developments, as well as to contribute to the overall assessment of systemic risk in

the EU financial system. The EBA stress tests are conducted in a bottom-up fashion, using methodologies, scenarios and key assumptions for simplification and consistency reasons.

A number of studies indicate that the post-crisis implementation of the regulatory stress tests had a substantial impact on the changes in bank behaviour on the singular institutional level (Acharya et al., 2018; Bassett and Berrospide, 2018; Pierret and Steri, 2019). The forward-looking nature of the stress test exercises that allows projecting the amount of the capital required to maintain in the future under the adverse economic conditions naturally leads to a variety of ex-ante responses of the banks. Given the high level of complexity of banking institutions, the diversity of business models and portfolios sensitivities there is a concern about the extent of the impact of banks' adjustments to additional capital requirements and enhanced regulatory scrutiny (Andersen et al., 2019; Bräuning and Fillat, 2019). This paper addresses this issue by exploring in-depth the time-dynamic causal effect of regulatory stress tests on a bank's investment strategies and portfolio choices. From a financial stability perspective, it is crucial to know how the banks react to enhanced scrutiny and adjust their balance sheets over the longer time horizon because this reaction can have a substantial impact on other financial intermediaries, thus affecting the real economy. 
The focus of our article is on the investigation of changes in the portfolio structures and investment decisions associated with EU-wide stress test rounds in 2011, 2014 and 20161. We develop a novel empirical strategy within the econometric framework of the causal inference and event study. The heterogeneity of treatment effect is studied on the group and individual unit level and by taking into consideration a variation in timing of the events. The difference-in-difference estimator in generalized form has been employed to evaluate the treatment effect in time-dynamic settings. Next, we study the heterogeneity of treatment effect on individual unit level by employing an instrumental variable (IV), that is manually constructed on the basis of the publicly available results of EBA regulatory stress test rounds in 2011, 2014, 2016 and methodologies of Acharya et al. (2014); Eber and Minoiu (2016).

We find that regulatory stress testing contributes to a decline of risk density of portfolios, which is mostly attributable to a decrease in its numerator i.e. risk-weighted assets. Seemingly it does not affect the realized risk that is measured by the proportion of non-performing exposure in portfolios. We argue that regulatory stress testing incentivizes banks to altering a mix of assets in their balance sheets towards less capital-intensive areas, while the overall risk remains seemingly unchanged. On the other hand, we observe that the enhanced regulatory scrutiny prevents the stress-tested banks from engaging in risky behaviour i.e. increase risk in a portfolio or excessive loan growth. Thus, the regulatory stress testing fulfils its objective of promoting prudent risk management practices. Our results are robust in a number of alternative specifications such as: modelling with instrument variable in the continuous form within the treated sample and under less restrictive assumptions of the structural equations and based on the alternative samples.

Our contribution to the literature is twofold. First, our study contributes to the banking literature that specifically focuses on investigating the implications of regulatory policies on stress testing and capital requirements for the banking institutions (Ahnert et al., 2018; Bassett and Berrospide, 2018; Calem et al., 2017; Cohen and Scatigna, 2016; Cortés et al., 2018; Goldstein and Sapra, 2014; Gropp et al., 2018; Mésonnier and Monks, 2014; Pierret and Stex`ri, 2019; Schuermann, 2013; Stádník et al., 2016; Sutorova and Teply, 2013; Vozková and Teplý, 2018). We extend this literature by providing evidence, based on the novel identification strategy with the application of the approach i.e. we compare forward-looking values with historical data. 
causal inference methods that allow us to isolate the effects of regulatory stress test from other capital regulations and analyse the heterogeneity of treatment effect in time-dynamic settings. Second, our results have important implications for the supervisors since we shed some light on the dynamic of bank behavioural responses to the regulatory scrutiny of stress tests.

The rest of this article is structured as follows: Section 2 reviews the prior literature, institutional background and develops our hypotheses; Section 3 provides details on the dataset, the sample matching strategy and description of the variables; Section 4 elaborates the identification strategy and describes the empirical methods in detail; Section 5 presents results of empirical methods; Section 6 provides a series of robustness checks for testing the results of baseline specification; Section 7 summarizes the results and implications and concludes the study.

\section{Related Literature and Institutional Background}

\subsection{Literature review}

The role of the regulatory stress testing and its impact on financial stability and institutions have attracted recently considerable attention from researchers and policymakers. There are several strands of literature in this context. The first stream of literature is dealing with questions of optimal disclosure and asymmetric information associated with it. The second one focuses on the reaction of markets and investors to the announcements of the regulatory stress tests events and published results. The studies that investigate the impact of regulatory stress tests on the individual bank's conduct due to the additional capital requirements and stricter supervision are the closest to our analysis.

It is well known that the banks are complex institutions whose assets are difficult to evaluate by external parties, for example, creditors, regulators or other market participants. The benefits of managing the asymmetry information in lending markets are clearly emphasized in seminal works of Campbell and Kracaw (1980); Diamond (1984); Leland and Pyle (1977). Given the high level of information disclosure of the insights into portfolio risk and balance sheets of the financial institutions, there are a number of studies highlighting the concerns about the hidden costs of disclosing banks financial information and stress test results. For example, Goldstein and Sapra (2014) argue that by promoting financial stability and market discipline from a macroprudential perspective, disclosure of stress test results may exacerbate bank-specific inefficiencies by changing 
the ex-ante incentives of managers. As stress tests become routine, supervisors need to be mindful of potential disadvantages of detailed disclosure of the results at the bank-specific level. The reduction in risk-sharing opportunities in the interbank market and potential panics among bank creditors and other bank counterparties are important consequences associated with it. Some researchers also point out the issues with the interpretation of published results of stress tests e.g. it might imply an official endorsement of the health of an institution (Schuermann, 2013) or implicit assurance that regulators would in some way absorb losses in excess of the stress test estimates (Flannery, 2013).

Goncharenko et al. (2018) suggest that the information disclosure lowers the expected risk-adjusted profits for a non-negligible fraction of banks. In their empirical analysis of 2011 and 2014 stress tests, they conclude that the magnitude of this effect depends on the structure of the banking system. Alarmingly, it is more valid for the largest and systemically important institutions. The differences in the level of disclosure between the stress-tested banks and non-stressed ones create the informational asymmetry and impede a market of risk-sharing (Georgescu et al., 2017). This increases volatility on interbank markets and leads to the discrepancy between banks funding costs and their risk profile.

Macroprudential regulations of the financial institutions intend to reduce the risks to the financial system by building-up the capital buffer in the system large enough to absorb the losses in adverse economic conditions. Acharya et al. (2014) argue that these regulations force institutions to internalize their contribution to systemic risk. In this respect, there is a vast body of literature dealing with channels of transmission of the additional capital requirements, regulatory monitoring costs and their implications. Among the primary channels of the transmission are the adjustments in bank's balance sheets or portfolio composition structure (Bräuning and Fillat, 2019). They suggest that while the individual portfolios of the largest US banks have become more diversified, the greater convergence of the portfolios held by these banks may be inadvertently increasing the aggregate banking sector's systemic risk factors. Acharya et al. (2018) investigate the risk-taking behaviour of US banks subject to the regulatory stress tests since the Dodd-Frank Act. Their findings are consistent with the "risk management hypothesis", under which stress-tested banks reduce credit supply, particularly to risky borrowers with the aim of decreasing their credit risk. Also, their results do not support the "moral hazard hypothesis", according to which these banks expand credit supply especially to risky borrowers that pay high spreads and as a 
result increase their risk. Acharya et al. (2015) provide an in-depth analysis of how the capital requirements can address moral hazard problems in banking associated risk shifting and managerial under-provision of effort in loan monitoring.

There is mixed empirical evidence on the impact on lending activities and credit supply. Some researches point out a negative effect on lending activities e.g. Mésonnier and Monks (2014) use the banks' balance sheet data to show that overall loan growth decreased at the banks included in the EBA stress test exercise. They find that forcing a banking group to increase its core tier 1 capital by 1 per cent of risk-weighted assets was associated with a decrease of 1.2 percentage points in credit supplied by banks in the same group over the nine-month period of the capital exercise. Similarly, Gropp et al. (2018) show that banks in the 2011 European Banking Authority's capital exercise increased their capital ratios not by raising their levels of equity, but by reducing the credit supply. The lending volumes to firms decrease for banks subject to the EBA's 2011 capital exercise relative to those that were not included. As a result, firms more exposed to EBA banks reduce total assets, fixed assets, and have lower sales following the exercise. Eber and Minoiu (2016) using the regression discontinuity approach to EBA's stress testing framework, find that banks adjust to stricter supervision by reducing their leverage, and most of the adjustments stem from shrinking assets rather than from raising equity. In contrast, the results of Bassett and Berrospide (2018) show that among the stress-tested banks in the US, more capital is associated with higher loan growth. The higher capital implied by supervisory stress tests relative to that suggested by the banks' own models does not appear to unduly restrict loan growth. The studies of Cortés et al. (2018) show that post-crisis stress tests have altered banks' credit supply to small business. The stress-test-affected banks raise interest rates on small business loans and reduce the supply of credit to risky borrowers. Similarly, Pierret and Steri (2019) indicate that stress tests effectively prevent excessive risk-taking by bringing stricter supervision on the investment portfolios of stressed banks. Though, the higher capital requirements are not a substitute for regulatory scrutiny to promote prudent lending. They argue that the correction in regulatory capital charges originating from stress tests effectively reduces risky lending.

A number of empirical papers perform the event studies and document a strong market reaction to the announcement of dates and results of stress tests (Ahnert et al., 2018; Candelon and Sy, 2015; Carboni et al., 2017). Most of the studies indicate that the investors gained valuable information due to the disclosure. For 
example, Petrella and Resti (2013) suggest that the EBA stress test in 2011 achieved its goal to restore confidence and to curb bank opaqueness by helping investors distinguish between sound and fragile institutions. While comparing the outcomes of the results of EBA stress tests to those from alternative methodology on the calculation of capital shortfall (SRISK) that relies on publicly available market data, Acharya et al. (2014) conclude that the continued reliance on regulatory risk-weights in stress tests appears to have left financial sectors undercapitalized. This happened especially during the European sovereign debt crisis, and it likely also provided perverse incentives to build up exposures to low risk-weight assets.

Another stream of literature is related to the discussions on the calibration of methodologies of stress tests from macro and microprudential perspective (Andersen et al., 2019; Stádník et al., 2016; Witzany, 2017a). In the EU, EBA stress tests are run under the static balance sheet assumption. In the so-called "constrained bottom-up" stress test (European Banking Authority, 2016; European Central Bank, 2019), maturing assets and liabilities are replaced with similar financial instruments, and management actions are restricted. This methodology does not allow for mitigating management actions, such as changes in the composition and size of the balance sheet. In this view, some researchers perform the stress tests under the alternative assumptions that are acknowledging a broad set of interactions and interdependencies between banks, other market participants, and the real economy (Budnik et al., 2019; Busch et al., 2017). They highlight the importance of the initial level of bank capital and bank asset quality.

Based on the assessment of the publicly disclosed results for four rounds of stress tests in the US, Glasserman and Tangirala (2016) find that the stress testing process has evolved and its outcomes have become more predictable. Therefore, they are arguably less informative to market participants. They suggest an opportunity to get more information out of the stress tests through the greater diversity in the scenarios to be used.

\subsection{Institutional framework of EU-wide stress tests and hypotheses development}

The EU-wide stress test is part of the supervisory toolkit used by banking authorities to assess banks' resilience to adverse shocks. It aims to strengthen market discipline and transparency through the publication of consistent and granular data on a bank-by-bank level. The first stress test exercises were conducted in 2009, 2010 on the EU level by the Committee of European Banking Supervisors (CEBS) and later on by European Banking Authority 
(EBA). With the introduction of Single Supervisory Mechanism (SSM) in 2014, EU-wide stress test is the second pillar of EBA Comprehensive Assessment (CA) along with the Asset Quality Review (AQR) as the first pillar. The EBA stress test rounds were conducted in 2014, 2016 and 2018.

The regulatory EU-wide bank stress tests are the analyses to assess the capitalization of banks on a forwardlooking basis under the economic shocks. They test how the decline in profitability and the quality of the bank's assets under adverse economic conditions translates into a hypothetical loss. The riskiness of the banks' assets increases in the stress scenario, resulting in higher regulatory risk-weights assigned to risky exposures and correspondingly lower the post-stress capital ratios defined as a percentage of risk-weighted assets. The economic scenarios usually cover "baseline" and "adverse" cases, and they are forward-looking over 2-3 years horizon. To assess the capital adequacy of all banks subject to the stress test exercise from 2011, the EBA uses one of the main measures, the capital ratio "Common Equity Tier 1 Ratio" defined as:

$$
\operatorname{CET} 1 R_{t}=\frac{K_{t}}{R W A_{t}}
$$

where $K_{t}$ denotes a Common Equity Tier 1 capital, that consists primarily of the common equity and earnings without considering any additional or hybrid capital. $R W A_{t}$ is the risk-weighted assets measure at the end of reporting period $t$.

In essence, supervisory stress tests can be considered as dynamic capital requirements that impose risk-sensitive capital buffers on banks. They account explicitly for expected deterioration stemming from adverse economic conditions. From a theoretical perspective and assuming that capital is a higher cost source of funding than the bank would otherwise employ, risk-sensitive capital requirements create stronger incentives for banks to limit risk-taking activities (Bassett and Berrospide, 2018). Following theoretical and empirical literature that relates the level of capital to optimal investment behaviour by banks, we formulate our hypotheses about the impact of the hypothetical capital gap or extra capital implied from the supervisory stress tests on the banks' conduct. The risk management hypothesis (reduction in credit supply) and the moral hazard hypothesis (increase in credit supply) of stress tests are proposed and tested in (Acharya et al., 2018, 2015; Cohen and Scatigna, 2016). In their studies, they indicate the channels set forth through which bank capital regulations impact bank risk-taking and lending decisions. These channels are derived under the view that depending on how strong their existing capital positions 
are, banks may have incentives to reduce or expand their lending or in other words to change the investment strategy or portfolio structure in response to the available capital resource. Therefore, we focus primarily on the causal effects of regulatory stress tests on banks' risk behaviour and performance from the perspective of actual and targeted capital, that banks could employ or on opposite lack as a result of the supervisory stress tests. In addition, the bank units subject to regulatory stress tests face enhanced scrutiny through the qualitative assessments of portfolio and capital plans. This monitoring and supervision effect of regulatory stress tests should incentivize banks to follow more prudent business practices when making investment decisions and portfolio risk management. From these standpoints, we formulate the specific questions that we attempt to answer using the proposed empirical methods:

i) Do the banks adjust their portfolios and investment strategies in response to the regulatory stress tests?

ii) How heterogeneous is the impact within the treated group i.e. when we consider the banks participating in three rounds of EBA stress tests?

iii) How the inclusion into the regulatory stress test affects the ex-post realization of risk measured by a proportion of non-performing loans in the portfolio?

\section{Data}

\subsection{Dataset construction and sample matching strategy}

The first step of data construction consists of a mapping of individual banks that participated in the EU-wide stress test rounds in 2011, 2014 and 2016. The banks from this sample belong to the treated group and will hereon be referred to as "stress-tested" banks. While the other banks that never participated in the regulatory stress test, belong to the control group and are named as "non-stressed banks".

For compiling the treated group, we use the published results of stress tests in 2011, 2014 and 2016 conducted by the EBA. The financial institutions are located in the EU and EEA countries with Single Supervision Mechanism and the Denmark, Norway, Sweden and the UK. The number of banks that participated in separate stress tests were 90 in 2011, 123 in 2014 and 51 in 2016. The earlier results of the regulatory stress test performed by CEBS in 2010, were excluded from our study because the methodology of the stress test and metrics of results deviate from those used in other stress tests. Thus, this could distort the consistency of findings from analysis on the 
individual bank level. Naturally, we also do not consider the results of 2018 stress test. Because of the forwardlooking metrics, the 2018 stress tests are not suitable for our econometric approach i.e. comparison of ex-post results with historical data. Figure 1 depicts the timeline of stress tests and observational window, as well as the statistics on our participating banks.

Figure 1. EU-wide stress tests timeline and our sample

\begin{tabular}{|c|c|c|c|c|c|c|c|c|c|c|}
\hline \multirow[b]{2}{*}{$\begin{array}{l}\text { EBA stress tests dates: } \\
\text { (from announcement to } \\
\text { published results) }\end{array}$} & \multirow[b]{2}{*}{2010} & \multicolumn{8}{|c|}{ observation window } & \multirow[b]{2}{*}{2019} \\
\hline & & 2011 & 2012 & 2013 & 2014 & 2015 & 2016 & 2017 & 2018 & \\
\hline $30.10 .2018-02.11 .2018$ & & & & & & & & & $\mathrm{x}$ & \\
\hline 05.11.2015-31.07.2016 & & & & & & & $\mathrm{x}$ & & & \\
\hline $31.01 .2014-26.10 .2014$ & & & & & $\mathrm{x}$ & & & & & \\
\hline $13.01 .2011-17.07 .2011$ & & $\mathrm{x}$ & & & & & & & & \\
\hline $18.06 .2010-25.07 .2010$ & $\mathrm{x}$ & & & & & & & & & \\
\hline \# banks tested & 91 & 90 & & & 123 & & 51 & & 48 & \\
\hline of which in our sample & $\mathrm{n} / \mathrm{a}$ & 70 & & & 110 & & 51 & & $\mathrm{n} / \mathrm{a}$ & \\
\hline
\end{tabular}

Figure 1 depicts the timeline of stress tests considered in this study. The observation period is censored to the window of eight years to cover three rounds of stress tests conducted by CEBS and EBA in 2011, 2014 and 2016. We exclude the results of stress tests in 2010 by CEBS, since their metrics is not consistent with others. We do not include the most recent 2018 since they are out of scope i.e. ex-post study. Figure 1 includes the statistics on the number of bank participants in the stress test rounds and in our sample (treated group). All data is taken from the official stress test reports available on the EBA website.

The entire dataset covers the period 2011-2018 and is represented by the balance sheet and risk metrics of the fiscal year-end (that is a calendar year-end). The period is censored to the window of 8 years from the first declared regulatory stress test exercises until the year 2018. This time horizon, in our view, captures both short term and long term effects on the adjustment in strategies of banks. Our underlying hypothesis is that the effect from enhanced regulatory scrutiny of the stress test is not static but that it is evolving over the time horizon e.g. from stronger effect during the first rounds to the weaker effect of the last rounds. This serves as a basic assumption for our identification strategy discussed later in the paper. 
As a next step, we merge by name the financial institutions which are a part of EU-wide stress tests (treated group) with financial data obtained from the database Bureau van Dijk BankFocus. Similarly, the sample of the control observations is obtained from the database Bureau van Dijk BankFocus. The financial data are further enhanced by manually extracted financials from annual reports and calculations to fill in the gaps in the data pool. For the financial data from the database, we apply an economic filter to include the commercial and savings bank institutions, and to sort out the non-bank financial institutions e.g. clearinghouses or institutions that fall under the category "bad banks" (e.g. Heta Asset Resolution AG). The dataset has been refined by excluding the governmental entities e.g. National Bank of Greece, and by uniting some of the separate entities belonging to the same holding e.g. Raiffeisen Group under the single entity to observe the dynamics over three rounds of the stress tests.

The EU-wide regulatory stress tests were run at the highest level of consolidation, thus we exclude the subsidiaries of the multinational banking groups2. By doing a manual check of the data, we find a number of banks that were merged, divested or liquidated over the period 2011-2018. We purge them of our dataset along with the banks reporting substantially missing data or errors, for example, due to changes in the ownership, level of consolidation, etc. As a result of all these modifications, we obtain the final sample of 442 bank units. This includes 111 stresstested banks in the treated group and the control group of 332 units that never took part in the EBA stress tests. The effect of removal of the merged, divested and liquidated banks results in a reduction of the sample by approximately $5 \%$.

The choice of the control group is critically important for estimating the causal effects to ensure the randomized set-up. Therefore, we need an appropriate matching strategy that allows us to combine it with the average treatment effect and the potential outcome framework. By selecting the units for the control group, we consider i) observable bank characteristics for selection into the program; ii) level of capitalization; iii) geography of entities in the treated group.

\footnotetext{
2 In case of countries, e.g. Latvia, Luxemburg, Malta, Slovenia, where the bank sector is small and mostly represented by subsidiaries of large multinational banking groups which are systemically important on national level, we include them into the control group to provide a more feasible counterfactual on country level.
} 
The participation in the EU-wide stress test exercise was not randomly assigned to the banks. The selection into the sample is based on the several criteria, such as the size of the assets of the banking group and highest ranking for systemically important institutions on the national level (more detailed in Appendix Table III). EBA selection criteria result in the stress-tested banks being on average larger than non-stressed banks. In our sample, the minimum size of total assets for the banks which participated in the EU-wide stress test in 2011 was approximately 500 million EUR (Colonya, Caixa D'estalvis De Pollensa). This amount serves as a minimum threshold for selecting the banks into the control group.

The stress tests represent the forward-looking capital requirements on a single bank-unit level and in standard practice, these are a part of the internal process of capital targets setting. Thereby, the existing level of capitalization plays a significant role in ex-ante portfolio choice and in setting of the banks' capital targets (Andersen et al., 2019; Camara et al., 2013). In order to capture the single effect of regulatory stress test from other capital regulations and in order not to distort the assessment of average treatment effect, we match the control group by similar level of capitalization to those of the treated group. The final result is tested by performing the t-test for the two groups of units, depicted on Panel B in Table 1.

To mitigate concerns that our results are driven by cross-country differences, such as national regulatory interventions or business cycles, for the control group we choose the banks located in similar countries as treated 3 . Panel A in Table 1 exhibits the bank characteristics of all banks in the sample, while Panel B reports characteristics of separate groups of treated and non-treated units, and provides the results of t-test on significance in the difference in mean. The full list of the bank in the treated group is provided in Appendix Table IV.

Table 1. Descriptive statistics of treated (stress-tested) and control (non-stressed) groups in the sample

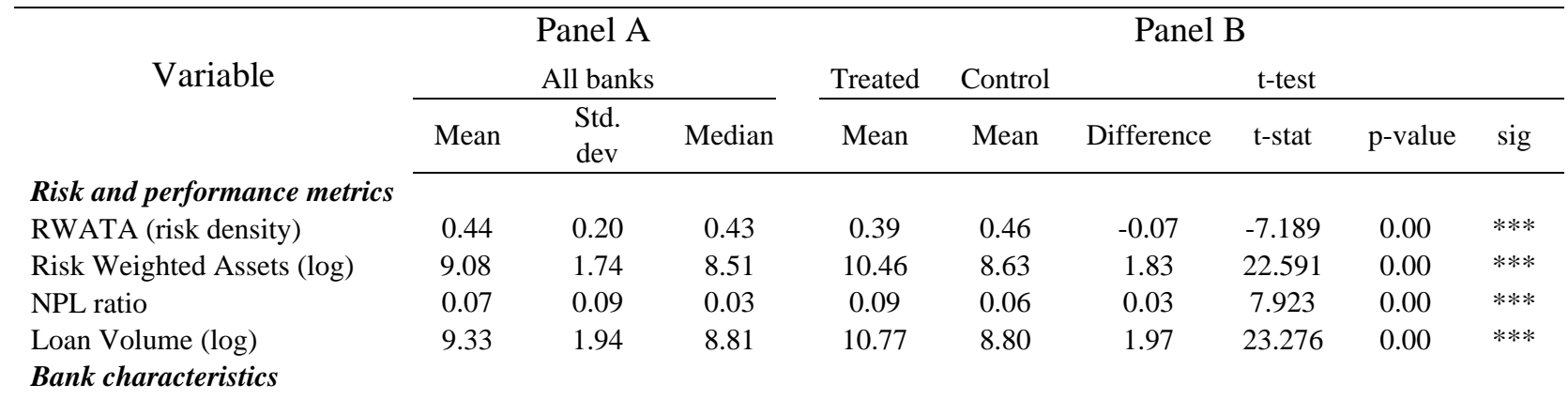

3 The treated group comprises of banking institutions from the following countries: AT, BE, CY, DE, DK, ES, FI, FR, GR, HU, IE, IT, LU, LV, MT, NL, NO, PL, PT, SE, SI and UK 


\begin{tabular}{|c|c|c|c|c|c|c|c|c|c|}
\hline CET1 ratio & 0.16 & 0.07 & 0.14 & 0.16 & 0.16 & -0.01 & 0.413 & 0.68 & \\
\hline Capital Adequacy Ratio & 0.18 & 0.07 & 0.17 & 0.18 & 0.18 & 0.00 & -0.363 & 0.71 & \\
\hline Size $(\log \mathrm{TA})$ & 9.45 & 1.65 & 9.34 & 11.40 & 9.45 & 1.95 & 23.249 & 0.00 & $* * *$ \\
\hline Liquidity Ratio & 0.20 & 0.16 & 0.14 & 0.17 & 0.20 & -0.03 & -5.847 & 0.00 & $* * *$ \\
\hline Funding Ratio & 0.75 & 0.24 & 0.83 & 0.71 & 0.75 & -0.04 & -4.934 & 0.02 & $* * *$ \\
\hline Cost-to-income ratio & 0.65 & 0.33 & 0.64 & 0.62 & 0.65 & -0.03 & -2.144 & 0.03 & $* * *$ \\
\hline Net Interest Margin & 2.02 & 2.76 & 1.56 & 1.56 & 2.02 & -0.46 & -4.142 & 0.00 & $* * *$ \\
\hline Total number of bank units & 442 & & & 110 & 332 & & & & \\
\hline
\end{tabular}

In Appendix Table I we provide more detailed definitions of the variables and sources of information.

\subsection{Variables and descriptive statistics}

\section{Outcome variables}

The outcome variables of our interest are the risk indicators that are commonly used as measures of portfolio riskiness: the annual change in the "risk density" that is a ratio of the risk-weighted assets to total assets (RWATA) and the annual change in the ratio of non-performing loans to total portfolio (NPL) (Berger and Bouwman, 2012; Camara et al., 2013; Janda and Kravtsov, 2018; Jeitschko and Jeung, 2006; Teplý et al., 2015). RWATA shows the proportion of risky assets in portfolio, but it may also reflect the manager's choice and strategy with respect to the asset mix in the portfolio. The second dependent variable ( $\triangle$ NPL) is an annual change in the ratio of nonperforming loans to the total loans on the balance sheet. Our third dependent variable ( $\triangle$ LOAN) denotes the annual change in loan volumes and captures the effect on the banks' lending activities. It describes the portfolio growth and can be analysed in the context of applied risk indicators. For example, the changes in loan volumes are associated with standard banking operations and may reduce the NPLs ratio, but an abnormal growth rate would indicate too risky strategy that eventually could result in deterioration of the portfolio quality (Zhang et al., 2016).

\section{Observable bank characteristics (Controls)}

The participation in EU-wide stress tests exercises was assigned according to the size of assets on the single bank unit level and also on the national level to cover the total assets of 50\% of the country banking sector. The explicit selection rule based on bank size implies that selection into the regulatory stress test exercise was based on observable characteristics. We exploit this exogenous variation in the bank selection rule for the selection of 
relevant observable covariates of the treated and control group. These matching covariates capture potential differences also associated with the size of assets, such as business model and efficiency, funding and liquidity strategies. Hence, upon the knowledge of observable characteristics and excluding the possibility of self-selection into the program, we restore the randomization in "non-experimental" design (Wooldridge, 2012).

The business model, efficiency and performance are represented by ratios of net interest margin (NIM) and cost to income ratio (COST) (Kuc and Teply, 2015; Teplý et al., 2015). NIM reveals the amount of money that a bank is earning in interest on loans compared to the amount it is paying in interest on deposits. Net interest margin varies among banks depending on their business models. Similarly, the cost-to-income ratio differentiates between institutions emphasising commercial banking and retail activities (Roengpitya et al., 2017). Less efficient banks or institutions with higher non-interest income may have been tempted to take higher risks to offset the loss of return due to the higher capitalization or low-interest environment (Vozková and Teplý, 2018). The funding and liquidity structure are represented by ratios of customer deposits to total liabilities (DLR) and liquidity ratio (LAR) of liquid assets, such as cash and short-term tradable securities to total assets. The larger institutions tend to have a larger proportion of wholesale funding and with a reference to regulations on Liquidity Coverage Ratio (LCR), Net Stable Funding Ratio (NSFR) they are penalized for the dependence on shorter-term funding, therefore the funding and liquidity structure is important characteristic to account for. The level of capitalization is measured in our analysis by capital adequacy ratio (CAR) that is a ratio of regulatory capital to total risk-weighted assets. Similarly, many of the larger size banks are a subject to additional capital requirements because of the systematically important institutions, therefore they are required to maintain higher capitalization level e.g. countercyclical capital buffers, systemic risk buffers, etc. These are not a part of the core capital i.e. CET1 ratio and therefore, we consider them as heterogeneous bank capital characteristics.

\subsection{Effect of capitalization on portfolio adjustments in treated and control groups}

By set-up, the supervisory stress tests can be considered as dynamic capital requirements that impose risksensitive capital buffers on banks in case of hypothetical adverse economic conditions. Even though there is no final consensus between theory and empirical evidence, how the regulatory capital requirements impact bank's risk and investment strategies, most researches admit a strong link in such relationship (Aggarwal and Jacques, 2004; Berger and Bouwman, 2012; Besanko and Kanatas, 1996; Furlong and Keeley, 1991; Jeitschko and Jeung, 
2006; Lindquist, 2003; Shrieves and Dahl, 1992). In our sample, we also observe that the changes in capitalization (CET1 ratio) affect both groups of the stress-tested banks (treated) and non-stressed banks (control). In both groups, it is evident that the increase in the capital ratio is associated with a decline in risk-density (RWATA) that is a ratio of risk-weighted assets to total assets. In Table 2, the columns (1) and (2) coefficients exhibit the statistical significance for the outcome variable of the annual changes in risk density ratio (RWATA). Such effect is mostly due to the decrease in risk-weighted assets (RWA) in columns (6) and (7) that can be attributable to a variety of reasons from portfolio optimization, changes in business models, or approach to the calculation of riskweighted assets (both ratios share the component) e.g. from the standard approach to the internal rating-based (IRB), advanced-IRB, etc. Notably, we observe no impact on the changes in the quality of portfolio measured as a proportion of non-performing exposure to total portfolio, while there is a simultaneous decrease in the loan volumes indicated for both groups.

This preliminary analysis implies that the regulatory stress tests can affect portfolio structure and investment decisions ex-ante through the difference in capital planning processes. So our task is to build up the identification strategy that allows, first of all, to isolate the effect of the regulatory stress testing from others, mostly the regulatory capital regulation and policies. Secondly, we have to establish a direct causal link between the regulatory scrutiny from stress tests and the changes in portfolio structures contingent on the variation in the timing of the rounds of the stress tests.

Table 2. Changes in capital ratio and portfolio composition in the treated and control group

\begin{tabular}{|c|c|c|c|c|c|c|c|c|c|c|}
\hline \multicolumn{11}{|c|}{ Dependent Variable Annual Change (in pp or \%) } \\
\hline & (1) & (2) & (3) & (4) & (5) & (6) & (7) & $(8)$ & (9) & $(10)$ \\
\hline VARIABLES & $\begin{array}{c}\text { RWATA } \\
\text { Treated }\end{array}$ & $\begin{array}{c}\text { RWATA } \\
\text { Control }\end{array}$ & $\begin{array}{c}\text { NPL } \\
\text { Treated }\end{array}$ & $\begin{array}{c}\text { NPL } \\
\text { Control } \\
\end{array}$ & $\begin{array}{c}\text { RWA } \\
\text { Treated }\end{array}$ & $\begin{array}{c}\text { RWA } \\
\text { Control }\end{array}$ & $\begin{array}{l}\text { LOAN } \\
\text { Treated }\end{array}$ & $\begin{array}{l}\text { LOAN } \\
\text { Control } \\
\end{array}$ & $\begin{array}{c}\text { TA } \\
\text { Treated }\end{array}$ & $\begin{array}{c}\text { TA } \\
\text { Control } \\
\end{array}$ \\
\hline$\triangle \mathrm{CET} 1 \mathrm{R}$ & $\begin{array}{c}-0.006^{* * *} \\
(0.002)\end{array}$ & $\begin{array}{c}-0.004 * * * \\
(0.001)\end{array}$ & $\begin{array}{l}-0.000 \\
(0.001)\end{array}$ & $\begin{array}{l}-0.000 \\
(0.000)\end{array}$ & $\begin{array}{c}-0.021 * * * \\
(0.006)\end{array}$ & $\begin{array}{c}-0.015 * * \\
(0.006)\end{array}$ & $\begin{array}{c}-0.005^{* *} \\
(0.002)\end{array}$ & $\begin{array}{l}-0.006^{*} \\
(0.003)\end{array}$ & $\begin{array}{c}-0.001 \\
(0.004)\end{array}$ & $\begin{array}{l}-0.002 \\
(0.002)\end{array}$ \\
\hline Constant & $\begin{array}{c}0.338 \\
(0.521)\end{array}$ & $\begin{array}{c}0.458 * * * \\
(0.139)\end{array}$ & $\begin{array}{l}-0.092 \\
(0.262)\end{array}$ & $\begin{array}{c}0.051 \\
(0.075)\end{array}$ & $\begin{array}{l}-1.233 \\
(0.973)\end{array}$ & $\begin{array}{c}0.527 \\
(0.935)\end{array}$ & $\begin{array}{c}-2.778 * * * \\
(0.686)\end{array}$ & $\begin{array}{l}-1.222^{*} \\
(0.642)\end{array}$ & $\begin{array}{c}0.050 \\
(0.076)\end{array}$ & $\begin{array}{l}-0.047 \\
(0.091)\end{array}$ \\
\hline Unit FE & Yes & Yes & Yes & Yes & Yes & Yes & Yes & Yes & Yes & Yes \\
\hline Time FE & Yes & Yes & Yes & Yes & Yes & Yes & Yes & Yes & Yes & Yes \\
\hline Controls & Yes & Yes & Yes & Yes & Yes & Yes & Yes & Yes & Yes & Yes \\
\hline Observations & 547 & 1,497 & 479 & 1,329 & 549 & 1,486 & 547 & 1,510 & 546 & 1,512 \\
\hline R-squared & 0.268 & 0.249 & 0.363 & 0.254 & 0.322 & 0.407 & 0.321 & 0.343 & 0.361 & 0.397 \\
\hline Adj $R_{2}$ & 0.100 & 0.0545 & 0.213 & 0.0507 & 0.165 & 0.251 & 0.165 & 0.176 & 0.217 & 0.245 \\
\hline $\mathrm{F}$ test & 0.000 & 0.000 & 0.003 & 0.001 & 0.000 & 0.000 & 0.000 & 0.000 & 0.000 & 0.000 \\
\hline
\end{tabular}


In Table 2, we report the results of the regression model: $\Delta Y_{i t}=\alpha_{i}+\delta_{t}+\beta_{2} \Delta C E T 1 R_{i t}+\gamma^{\prime}$ controls $_{i t}+\varepsilon_{i t}$, where $\alpha_{i}$ is unit and $\delta_{t}$ is a year fixed effect, and $\varepsilon_{i t}$ is i.i.d error term. The observed outcome $\Delta Y_{i t}$ denotes annual changes in portfolio metrics such as risk density (RWATA), realized risk (NPL), loan volumes (LOAN) and total assets (TA). Importantly, one of our controls is the explanatory variable $\Delta C_{i t}$ that represents the annual change in Common Equity Tier 1 capital ratio as: $\Delta C_{i t}=C E T 1 R_{i t}-C E T 1 R_{i t-1}$. Finally, we control on bankspecific observable characteristics, namely: the size of the bank's assets, a level of efficiency, funding and liquidity structure, capitalization, with more details described in Section 3.2.

Note: Robust standard errors are presented in parentheses and statistical significance is denoted as $* * * \mathrm{p}<0.01, * * \mathrm{p}<0.05, * \mathrm{p}<0.1$. The standard errors are clustered on the bank-unit level to alleviate the heteroscedasticity bias. To test for multicollinearity issues in this specification, the Variance Inflation Factor (VIF) was computed. The results of the test (all VIFs close to 1) confirm the absence of multicollinearity issues.

\section{Empirical Strategy}

The primary goal of our analysis is to examine the impact of regulatory stress tests on the adjustment strategies in portfolio and changes in investment decisions of the EU banks that were a subject of the regulatory stress tests. We adopt the causal inference methods to estimate a treatment effect in event study design, based on the data of the stress tests rounds conducted by EBA in 2011, 2014 and 2016. Thereby, the inclusion of an individual bank into the EBA regulatory stress test is considered as a treatment effect. Statistically speaking, we aim to explore the heterogeneity of treatment effect that arises from variations in responsiveness to treatment:

i) on group level (comparing the stress-tested with non-stress tested banks);

ii) on individual unit level (the strength of the capital requirement effect for a single bank) and

iii) variation in the timing of treatment (event study).

To explore the heterogeneity of treatment effect on the group level (control versus treated group), we employ the difference-in-difference (DID) estimator in generalized form, whereby the source of causality stems from the comparison between two groups of treated and control before and after the inclusion into the regulatory stress test. The generalized form of DID provides flexibility to control simultaneously on the observable bank characteristics that could plausibly confound the effect of bank capital requirements on the outcome, and the time/unit fixed effects that absorb all unobserved individual and time-invariant factors.

Separately, we study in-depth the heterogeneity of the treatment effect on the individual unit level with the help of the constructed instrumental variable (IV) "buffer" (BUF). The instrument BUF allows to proxy for the 
variation in responsiveness of the individual bank to the economic shock that is pre-defined in EBA scenarios. This measure quantifies the capital gap or surplus available and in other words, represents the sensitivity of a bank's portfolio to a hypothetical economic shock. To fulfil its identification function as an instrumental variable (or continuous treatment variable4), the measure BUF needs to be exogenous from the outcome of our interest. To address this issue, we exploit the exogeneity of the economic scenarios and thresholds parameters defined by the sole discretion of banking authorities (EBA) for each stress test round. Across this study, we utilize BUF as a continuous treatment variable or IV in interaction terms with historical risk-adjusted capital ratio (CET1 ratio) to highlight the strength of the effect.

The inclusion of the individual banks into the EU-wide stress test framework is associated with enhanced scrutiny and regulatory monitoring and in general higher disclosure requirements and transparency of the portfolio and riskiness. This effect has a substantial contribution (Goldstein and Sapra, 2014), so we need to account for it since naturally, it affects the investment decisions and portfolio choices of the treated banks. The introduced interaction element with historical changes in CET1 ratio enables us to isolate the impact of enhanced regulatory scrutiny of regulatory stress tests from non-capital requirements (Pierret and Steri, 2019). To do so, we assume plausibly (see Section 3.3) that the changes in standard capital requirements or, specifically the regular capital requirements on CET1 ratios affect similarly both treated and control group. Thus, the identification comes from the remaining effect in interaction terms with treatment variable or IV while accounting for the observable characteristics and confounding factors.

Next empirical challenge is to provide an unbiased assessment of treatment effect due to the variation in the timing of the events. To do so we employ the generalized form of DID estimator adopted to event study framework. Here we are also motivated by studies e.g. (Glasserman and Tangirala, 2016) indicating that the effects of regulatory scrutiny, particularly of the regulatory stress test are not static and that they are evolving over the time horizon. If the effect increases or decreases monotonically or linearly, or shows any other complicated time-related pattern, then the strength of the observed effect in a panel study is strongly dependent on the timing of the panel waves

\footnotetext{
4 Depending on the modelling type and its application, the measure "buffer" (BUF) serves as instrumental variable or continuous treatment variable.

5 More detailed see in the revised version of Basel III: A global regulatory framework for more resilient banks and banking systems https://www.bis.org/publ/bcbs189.htm
} 
i.e. temporal lags (Blossfeld et al., 2019). The overall strategy here is to restrict the pre-trends and apply full timedynamic settings with both unit/time fixed effects for complete sample (control and treated units). Practically, we censor the combined sample to the duration of the group treatment and account for the timing variation in treatment effect i.e. early or late participants, always or never participated units during the three waves of events, or in our case, the regulatory stress test rounds. The control group thus consists of never treated and not yet treated units and it provides valid counterfactuals for the group of already treated units. The causal effect of the intervention can be captured more precisely by comparing not only two groups, but also considering the multitiming of treatment. By doing so, we avoid the misidentification problem due to the extrapolation and negative weights when we employ the generalized DID estimator to not restricted sample (Borusyak and Jaravel, 2018).

\subsection{Measure of banks' capital requirement from the regulatory stress test}

In this section, we describe the mechanism of the constructing a measure "buffer" (BUF) to quantify the capital requirements from regulatory stress tests or in other words, the sensitivity of banks capital to hypothetical shocks. Building upon the methodology of Acharya et al. (2014) and Eber and Minoiu (2016), we exploit the exogeneity of the economic scenarios and thresholds parameters defined by bank supervision authority for each stress test round. We use these factors to calculate the sensitivity of a bank's capital and portfolio to the hypothetical economic shocks as pre-defined in EBA scenarios. To do this, we make use of the published results of EBA stress tests rounds in 2011, 2014, 2016 and calculate a projected "gap" or "surplus" in a stressed capital ratio (we name this measure a "buffer" since in our sample we identify a capital surplus for almost all banks in the sample).

According to the EBA stress test methodology, the bank's capital is supposed to absorb the projected losses under two stress scenarios: baseline and adverse. Therefore, there are minimum thresholds of capital i.e. Common Equity Tier 1 ratio (CET1R) to be reached under both scenarios. Under the baseline scenario, banks were required to maintain a minimum CET1 ratio of $8 \%$ and in case of the adverse scenario, a minimum CET1 ratio of 5-5.5\% that is also referred to as "hurdle rate" in EBA stress test methodology (see details on the stress tests in Appendix Table III). Even though from 2016 the hurdle rate is not explicitly referred to in the published results of EBA 
stress test rounds, we believe that the meaning of it as the benchmark remains the same as before. Besides, the hurdle rate is equivalent to existing minimum capital requirements on CET1 capital6.

In practice, we calculate the buffer as a capital surplus or gap of capital in percentage points needed to pass the minimum regulatory threshold (hurdle rate $k$ ) under the baseline or adverse economic scenario of the stress test (Acharya et al., 2014; Eber and Minoiu, 2016):

$$
B U F_{i t}=\min \left\{C E T 1 R_{i t}^{\text {baseline }}-k^{\text {baseline }}, C E T 1 R_{i t}^{\text {adverse }}-k^{\text {adverse }}\right\}
$$

The buffer also can be interpreted as an extra capital that each bank can employ as a result of the supervisory stress tests usually being more stringent than their own assessment based on the internal stress test models. Those banks that have a value of buffer around zero or minus (i.e. having a capital gap) failed and those banks with higher buffer (as approximation value $\geq 0.01$ ) passed the stress test exercise. Figure 2 shows historical CET1 ratios and corresponding buffer values, while more detailed descriptive statistics and distributional characteristics are presented in Appendix Table II. It is worth mentioning that in our sample, we observe on the average capital surplus in value of $4 \%$ (buffer $=0.04$ ) for all sample including three tests rounds. Only in a few cases (less than $5 \%$ in the sample), the banking institutions report capital gap (negative values of buffer), and thus formally they failed the regulatory stress test.

Figure 2. CET1 ratios and measure BUF for the period 2011-2018

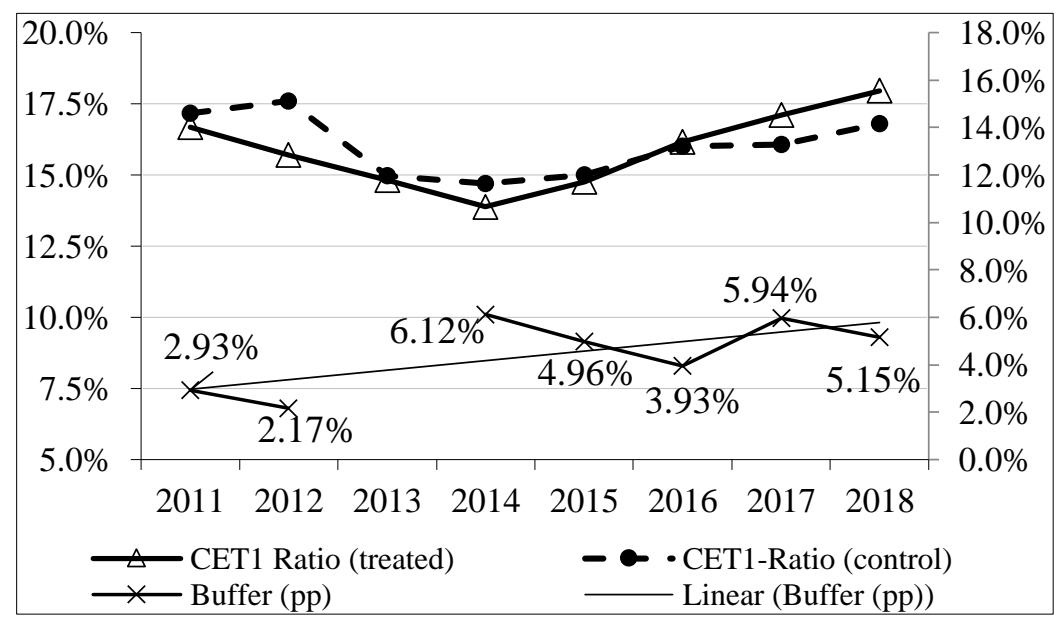

Note: in the Figure, we report unweighted average CET1 ratios for both treated and control group 
In line with our empirical strategy, we consider the observation window that covers a period from 2011 to 2018. It includes three round of stress tests and fits within the timeline of the instrumental variable (the data mapping of the instrumental variable exhibited in Figure 3). CEBS stress test conducted in 2010 has a methodology and metrics which are not consistent with subsequent stress test rounds, therefore, we don't consider it in our analysis. The proposed methodology of measure calculation causes an overlap in the data of buffer for the year 2016 since both stress tests in 2014 and 2016 have a three-year horizon. We solve this by taking the conservative stance, similar to the risk management in practice and choose minimum values from two stressed capital ratios. Moreover, the results of the stress test round in 2011 have a two-year horizon, effectively it leads to a gap in the estimation of the values of IV buffer for the year 2013. As a solution to this problem, we control the time fixed effects by including the full set of the time dummies corresponding to the years of available estimates of the buffer values i.e. excluding the year 2013 (only in the models with IV).

Figure 3. Data mapping of instrumental variable "BUF" for the period 2011-2018

\begin{tabular}{|c|c|c|c|c|c|c|c|c|}
\hline EBA Stress Test Round & 2011 & 2012 & 2013 & 2014 & 2015 & 2016 & 2017 & 2018 \\
\hline 2011 & & 90 & & & & & & \\
\hline 2014 & & & & & 123 & & & \\
\hline 2016 & & & & & & & 51 & \\
\hline Banks in our sample & & 0 & & & 106 & & 51 & \\
\hline
\end{tabular}

Source: EBA published results and own calculation. The Figure depicts the mapping of the data relevant to the projected capital gap/surplus that is a basis for the calculation of the instrumental variable BUF. We show the number of stress-tested banks on the grey area and a corresponding number of banks in our sample below in Figure.

The measure BUF serves two purposes: first, this is a non-binary or continuous treatment indicator in specification with treatment effects analysis in Eq. (5). Therefore it reflects the strength of treatment effect from capital requirements of EBA stress tests (as continuous treatment indicator). Second, as an instrumental variable (IV) it helps to isolate the capital requirements from stress tests from other regular capital requirements within the restricted sample of stress-tested banks in Eq. (8). Furthermore, in robustness check in Section 6.2, we use it as an IV, when we model the treatment effect in the form of structural equations and account for unobserved heterogeneity. 
In case of IV or as a continuous treatment variable, the measure buffer should be exogenous from the outcome variable of our interest to fulfil its identification function. A standard criticism of this measure as an identification function is that to some extent it can be endogenous to choices made by the bank (e.g. internal risk models might have the identical scenarios for the economic shocks as those proposed by regulators). Besides, it may be endogenous to unobserved variation in bank investment decisions and capital planning processes due to the publicly available information about methodologies of EBA stress tests. We argue that IV BUF can be exogenous for several reasons. First of all, because the type of scenarios and severity of the economic shocks along with sample selection criteria are changing every stress test round and these are defined on the sole discretion of EBA. Hence, it is highly doubtful that these can be influenced by a single bank or a group of banks. In reality, when the scenarios and hurdle rates become known to bankers the structural changes in portfolio and business models require longer horizon for such adjustments (projected scenarios for three-year horizon). There is an element of predictability when the processes of stress testing become a standard procedure for the banks. However, here comes a widely acknowledged concern about the routines and predictability of regulatory stress test processes and its danger that it will lead banks to optimize their choices for a particular supervisory hurdle and implicitly create new, harder to detect risks after a while (Glasserman and Tangirala, 2016). If it becomes a case in reality then it would diminish its value as a practical toolkit in identifying the potential risks of externalities, and hence there is a substantial degree of uncertainty expected to remain in assumptions and scenarios proposed by a banking authority in future.

\subsection{Portfolio adjustments in response to the regulatory stress tests}

We use a difference-in-difference (DID) estimator with the multi-timing treatment to study the bank's portfolio adjustments in response to three rounds of EBA regulatory stress tests. For this purpose, we employ the setting where units adopt the policy or treatment at a particular point in time, and then remain exposed to this treatment at all times afterwards (Athey and Imbens, 2018; Callaway and Sant'Anna, 2019). Let us consider a panel of $i=$ $1, \ldots, N$ units in which the outcome $Y_{i t}$ is observed for the $t=1, \ldots, T$ periods (calendar time). In our settings, every unit receives treatment at some period $E_{i}$ within the sample and stays treated forever. The indicator of treatment effect $W_{i}$ is taking a binary form of a value 1 for the treated unit and 0 for the unit that was not treated. Let $K$ indicate a number of periods before the event $E_{i}$, then it can be defined as $K_{i}=t-E_{i}$. This indicates the 
time of periods relative to the event $E_{i}$. Then, the indicator variable of being treated can be formulated as $W_{i t} \equiv$ $W\left(E_{i}, t\right)=1\left\{t \geq E_{i}\right\}=1\left\{K_{i t} \geq 0\right\}$. For each unit, we observe a treatment path that is a non-decreasing sequence of zeros and then ones, starting from event or adoption date (Abraham and Sun, 2018; Athey and Imbens, 2018). The group of treated units during the same period we refer to as a cohort $e$. If we denote the baseline outcome with treatment $Y_{i t}{ }^{e}$ and never treated as potential outcome $Y_{i t}^{\infty}$, then a treatment effect for a given event period and cohort of units can be defined as the difference between the baseline outcome and the potential outcome: $Y_{i t}{ }^{e}-Y_{i t}^{\infty}$. Thus, considering the timing of the events, the observed outcome for each unit is (Abraham and Sun, 2018) as in Equation (3):

$$
Y_{i t}^{o b s}=Y_{i t}^{\infty}+\sum_{1 \leq e \leq T}\left(Y_{i t}^{e}-Y_{i t}^{\infty}\right) \cdot 1\left\{E_{i}=e\right\}
$$

Specifically, we employ the difference-in-difference estimator in the generalized form of two-way (unit and time) fixed linear regression model for the panel data and saturate the model with interactions and confounding factors. The baseline specification is defined in Equation (4):

$$
\Delta Y_{i t}^{o b s}=\alpha_{i}+\delta_{t}+\tau \cdot W_{i t}+\beta \Delta C_{i t}+\gamma^{\prime} X_{i t}+\varepsilon_{i t},
$$

and in the interactions of the variable $C$ (capital ratio CET1R) with treatment indicator $W$ (in binary form or with continuous treatment variable BUF from Section 4.1 ) in Equation (5):

$$
\Delta Y_{i t}^{o b s}=\alpha_{i}+\delta_{t}+\tau \cdot W_{i t}+\beta(\Delta C \cdot W)_{i t}+\gamma^{\prime} X_{i t}+\varepsilon_{i t},
$$

where $i$ represents a bank unit, $t$ is the time-period, and where $\alpha_{i}$ is a unit fixed effect and $\delta_{t}$ is a year fixed effect included to control for variation over the time. The outcome variables of the risk and performance metrics are grouped in vector $Y$ and proxied by annual changes in risk density (RWATA) and its component (RWA), realized risk (NPL), and loan volumes (LOAN). The control variables $X_{i}$ are the observable characteristics of the treated and control bank units, namely: the size of the bank's assets, a level of efficiency, funding and liquidity structure, and capitalization, as described in Section 3.2. Finally, in this specification, we assume that the unobserved factor is distributed as $\varepsilon_{i t} \sim i i d\left(0, \sigma^{2}\right)$. 
The aggregate effect of the supervisory stress test on the adjustments in the portfolio is captured in Equation (4). The isolated effect of regulatory scrutiny from other capital requirements is modelled in Equation (5) by the element of the interaction between the binary treatment indicator $W_{i t}$ with changes in capital ratio $\Delta C_{i t}$ or in the alternative as a continuous treatment variable $B U F_{i t}$. The explanatory variable. $\Delta C_{i t}$ represents an annual change in Common Equity Tier 1 capital ratio as: $\Delta C_{i t}=C E T 1 R_{i t}-C E T 1 R_{i t-1}$.

We assume plausibly (see Section 3.3) that the regular bank capital requirements affect both treated and control groups identically with the exception: i) intrinsic difference in sensitivities of the portfolio to the hypothetic shock (in interaction with instrumented variable BUF); ii) other non-capital driven effects (in interaction with changes in CET1ratio) e.g. higher regulatory scrutiny and monitoring, or larger transparency and disclosure requirements. Importantly in Equation (5), we omit a main effect variable $\Delta C$ from the model to isolate the confounding effect of regular bank capital requirements on the outcome variables and to avoid the correlation issues with the other capital related independent variable specified in the model.

If we denote $\hat{\alpha}_{\text {ols }}, \hat{\tau}_{\text {ols }}, \hat{\beta}_{\text {ols }}, \hat{\gamma}_{\text {ols }}$ then the proposed specification in Eq. (4) without interaction with capital changes provides the estimates of OLS (Athey and Imbens, 2018; Imbens and Rubin, 2015) as follows:

$$
\left(\hat{\tau}^{o l s}, \hat{\alpha}^{o l s}, \hat{\delta}^{o l s}, \hat{\gamma}^{o l s}\right)=\underset{\tau, \alpha, \delta, \gamma}{\operatorname{argmin}} \sum_{t=1}^{T} \sum_{i=1}^{N}\left\{\Delta Y_{i t}-\alpha_{i}-\delta_{t}-\tau \cdot W_{i t}-\beta \Delta C_{i t}-\gamma^{\prime} X_{i t}\right\}^{2}
$$

and with the interaction to the capital changes as in Eq.(6), the estimates are:

$$
\left(\hat{\beta}^{o l s}, \hat{\tau}^{o l s}, \hat{\alpha}^{o l s}, \hat{\delta}^{o l s}, \hat{\gamma}^{o l s}\right)=\underset{\beta, \alpha, \delta, \tau, \gamma}{\arg \min } \sum_{t=1}^{T} \sum_{i=1}^{N}\left\{\Delta Y_{i t}-\alpha_{i}-\delta_{t}-\tau \cdot W_{i t}-\beta(\Delta C \cdot W)_{i t}-\gamma^{\prime} X_{i t}\right\}^{2}
$$

The final results of $\hat{\tau}_{\text {ols }}$ and $\hat{\beta}_{\text {ols }}$ in equations (6) and (7) respectively are consistent with average treatment effect on treated (ATET) and signify a potential causal effect from the enhanced regulatory scrutiny of the stress test. The least-square estimates $\hat{\tau}_{\text {ols }}$ and $\hat{\beta}_{\text {ols }}$ are commonly interpreted as the weighted average of ATETs across all cohorts (de Chaisemartin and D'Haultfœuille, 2018; Goodman-Bacon, 2018; Imai and Kim, 2019a). The estimated $\tau$ indicates whether the changes in portfolio are associated with the regulatory stress testing in general. While a finding that $\beta$ is statistically different from zero suggests that the bank's responses in question are 
associated with regulatory scrutiny or higher capital requirements caused by the regulatory stress tests. If none of the mentioned coefficients is statistically significant, except of $\gamma$ this indicates that the changes in risks are associated with endogenous bank characteristics and there is no evidence linked to participation in regulatory stress tests. Furthermore, we test the specification on the appropriateness of the linear regression with two-way fixed effects in comparison to DID estimator by a specification test for heteroskedasticity (White, 1980) as suggested in the studies of Imai and $\operatorname{Kim}(2019 b, 2019 a)$.

The key identifying assumption in the specification is that in the absence of treatment, treated units would have experienced the same trends in average outcomes as the control units i.e. parallel trends assumption. The standard DID estimator rely on the restriction that any omitted variables are either time-invariant group attributes or timevarying factors that are unit invariant. Together, these two restrictions supplemented with variation in the timing of the treatment, produce a spurious effect and lead to underidentification issues (Callaway and Sant'Anna, 2019; Imai and Kim, 2019b). In this specification in Eq.(4) and (5), we follow the solution to this issue proposed by (Athey and Imbens, 2018; Borusyak and Jaravel, 2018) and we restrict the pre-trends in "semi-dynamic" settings while keeping the unit and time fixed effects for complete sample (control and treated units). But to do so, we have to justify the absence of anticipation factor, so that the event becomes a randomly assigned adoption date, and consequently, neither the pre-trends nor expectations cannot influence the outcome. There are a few points that could provide a sound rationale for this. Due to the complexity of stress testing exercise, it is very difficult to judge affront the magnitude of the impact, even though the date is announced, the scenarios and methodology are known. The mixed market reaction of investors on the date of announcement of the stress test and the date of published results documented by (Candelon and Sy, 2015; Carboni et al., 2017) can also provide supportive evidence for this. Sometimes the inconsistencies and uncertainties on the supervisory side can contribute too (Agarwal et al., 2014). In Section 6, we provide a series of formal tests of the parallel trend assumption, where the results of tests confirm statistically the absence of the effect of anticipations and pre-trends. 


\section{Results}

\subsection{Regulatory stress tests and bank responses}

Table 3 reports the results together with specification tests of the baseline (Eq. 4) and model with interactions (Eq. 5) for four outcome variables: risk density (RWATA), risk-weighted assets (RWA), realized risk in portfolio (NPL) and loan growth. In overall, we observe that the inclusion into the regulatory stress test framework over the period 2011-2018 results in the decline of the risk-weighted assets, while not affecting the other metrics i.e. realized risk or loan growth. The inclusion is associated with the decline of 0.052 (column 3 ) percentage points in RWA. The magnitude of the effect is statistically increasing when we include the interaction with changes in the capital ratio (CET1) and instrument variable (IV) buffer "BUF" (in columns 9 and 11). A one percentage point of available surplus in hypothetical capital from the regulators stress tests results in the decline of the risk density (RWATA) by 0.057 percentage points and RWA by 0.282 per cent. Thus it provides evidence that the primary channel of adjustments is the banks concern about the capital intensive areas in the portfolio in view of targeted capital position. The findings are robust and the estimated coefficients are significant with confidence level 95\% and 99\%, and steadily increasing normal and adjusted R-values with inclusion of interaction terms in the models. It is valid for the event treatment variable in binary form, in column (3) and even more significant by interaction with the CET1 ratio and IV BUF, in columns (5) and (7), (9) and (11) respectively. We document that the separated impact of regulatory scrutiny accounts for the decline in risk-density by 0.005 percentage points and risk-weighted assets by 0.014 percentage points, while the effect of higher capital requirements contributes to the decline by 0.057 and 0.282 respectively.

Table 3. Results of a regression model with heterogeneous treatment effect in time-dynamic settings

\begin{tabular}{|c|c|c|c|c|c|c|c|c|c|c|c|c|}
\hline \multicolumn{13}{|c|}{ Dependent Variables Annual Change (pp and \%) } \\
\hline & (1) & (2) & (3) & (4) & $(5)$ & (6) & (7) & (8) & (9) & (10) & $(11)$ & (12) \\
\hline VARIABLES & RWATA & NPL & RWA & LOAN & RWATA & NPL & RWA & LOAN & RWATA & NPL & RWA & LOAN \\
\hline W & $\begin{array}{l}-0.011 \\
(0.012)\end{array}$ & $\begin{array}{c}0.005 \\
(0.005)\end{array}$ & $\begin{array}{c}-0.052^{* * *} \\
(0.023)\end{array}$ & $\begin{array}{c}0.001 \\
(0.021)\end{array}$ & $\begin{array}{l}-0.011 \\
(0.013)\end{array}$ & $\begin{array}{c}0.004 \\
(0.005)\end{array}$ & $\begin{array}{l}-0.054 * \\
(0.028)\end{array}$ & $\begin{array}{c}0.006 \\
(0.023)\end{array}$ & $\begin{array}{l}-0.019 \\
(0.016)\end{array}$ & $\begin{array}{c}0.002 \\
(0.004)\end{array}$ & $\begin{array}{c}-0.059^{* *} \\
(0.027)\end{array}$ & $\begin{array}{l}-0.002 \\
(0.022)\end{array}$ \\
\hline$\Delta$ CET1R x W & & & & & $\begin{array}{r}-0.005 * * * * \\
(0.002)\end{array}$ & $\begin{array}{l}0.001- \\
(0.001)\end{array}$ & $\begin{array}{r}0.014 * * * \\
(0.005)\end{array}$ & $\begin{array}{l}-0.004 \\
(0.003)\end{array}$ & & & & \\
\hline$\triangle \mathrm{CET} 1 \mathrm{R} \times \mathrm{W} \times \mathrm{BUF}$ & & & & & & & & & $\begin{array}{c}-0.057 * * * \\
(0.017)\end{array}$ & $\begin{array}{c}0.009 \\
(0.008)\end{array}$ & $\begin{array}{c}-0.282 * * * \\
(0.087)\end{array}$ & $\begin{array}{l}-0.060 \\
(0.038)\end{array}$ \\
\hline Constant & $\begin{array}{c}0.598 * * * \\
(0.175)\end{array}$ & $\begin{array}{l}-0.007 \\
(0.123)\end{array}$ & $\begin{array}{l}-0.069 \\
(0.552)\end{array}$ & $\begin{array}{c}-1.409 * * \\
(0.562)\end{array}$ & $\begin{array}{c}0.618^{* * * *} \\
(0.180)\end{array}$ & $\begin{array}{l}-0.003 \\
(0.122)\end{array}$ & $\begin{array}{l}0.027 \\
(0.457)\end{array}$ & $\begin{array}{r}-1.566 * * * \\
(0.534)\end{array}$ & $\begin{array}{c}0.508 * * * \\
(0.175)\end{array}$ & $\begin{array}{c}0.036 \\
(0.115)\end{array}$ & $\begin{array}{l}-0.054 \\
(0.431)\end{array}$ & $\begin{array}{c}-1.442 * * \\
(0.574)\end{array}$ \\
\hline
\end{tabular}




\begin{tabular}{|c|c|c|c|c|c|c|c|c|c|c|c|c|}
\hline Unit FE & Yes & Yes & Yes & Yes & Yes & Yes & Yes & Yes & Yes & Yes & Yes & Yes \\
\hline Time FE & Yes & Yes & Yes & Yes & Yes & Yes & Yes & Yes & Yes1 & Yes1 & Yes1 & Yes1 \\
\hline Bank Controls & Yes & Yes & Yes & Yes & Yes & Yes & Yes & Yes & Yes & Yes & Yes & Yes \\
\hline Observations & 2,039 & 1,808 & 2,035 & 2,056 & 2,039 & 1,808 & 2,035 & 2,053 & 2,039 & 1,805 & 2,035 & 2,056 \\
\hline $\mathrm{R}_{2}$ & 0.260 & 0.267 & 0.389 & 0.344 & 0.231 & 0.267 & 0.361 & 0.363 & 0.239 & 0.330 & 0.364 & 0.339 \\
\hline Adjusted R2 & 0.0816 & 0.0834 & 0.240 & 0.187 & 0.0461 & 0.0838 & 0.205 & 0.210 & 0.0556 & 0.161 & 0.208 & 0.181 \\
\hline $\mathrm{F}$ test & 0.000 & 0.000 & 0.000 & 0.000 & 0.000 & 0.000 & 0.000 & 0.000 & 0.000 & 0.000 & 0.000 & 0.000 \\
\hline \multicolumn{13}{|c|}{ White's test for Homoscedasticity: } \\
\hline chi2 & 385.55 & 859.45 & 536.98 & 89.50 & 366,31 & 427.05 & 536.98 & 83.56 & 370.10 & 634.93 & 584.98 & 58.37 \\
\hline Prob > chi 2 & 0.000 & 0.000 & 0.000 & 0.8069 & 0.000 & 0.000 & 0.000 & 0.990 & 0.000 & 0.000 & 0.000 & 0.9998 \\
\hline
\end{tabular}

Our results are in line with (Acharya et al., 2014; Plosser and Santos, 2018), who argue that the strong reliance on the stress tests metrics on the risk-weights leads to the incentives of risk-shifting to lower risk-weighted portfolio e.g. sovereign exposure and thus amplifying the sovereign risk or leading to underreporting the risk to regulators. By contrast to Bassett and Berrospide (2018) and Pierret and Steri (2019), we do not observe the negative effect on the lending activities, columns (4), (8) and (12), the coefficients are not statistically significant. Though, it can be attributable to the presence of heteroskedasticity problems in this specification as the results of the test (White, 1980) suggest. The outcome coefficients for changes in realized risk or portfolio quality (NPL) are not statistically significant in all specifications, columns (2), (6) and (10). So we conclude that the regulatory stress tests did not have any impact on the write-off strategies or changes in portfolio quality ex-ante.

\subsection{Heterogeneity within the sample of treated banks}

In this section, we study responsiveness to higher capital requirements from regulatory stress tests on the individual banks subject to the EU-wide regulatory stress tests. We conduct this empirical analysis to ensure that the results from previous Section 5.1 are not distorted by strong heterogeneity within the sample of the treated group. We employ the exogenous measure buffer (BUF) as an instrumental variable (IV) (it can be viewed also as a continuous, non-binary treatment variable) to identify the effect of higher capital requirements from regulatory stress tests on the portfolio composition within treated banks. By construction, BUF is a measure quantifying the surplus or gap of hypothetically projected stressed capital that is derived from the results of EBA stress tests rounds for participating banks (in Section 4.1 we provide detailed rational and calculations of this measure). 
Instead of attempting to identify a complete set of separate causes, we intend statistically to grasp more tractable task of identifying the marginal effect of the IV in causal interactions. Using the multiplicative interaction model (Brambor et al., 2006; Golder, 2005) or saturated model (Angrist and Pischke, 2009)7, we estimate the marginal causal effect of projected stressed capital (IV BUF) on the outcome of our interest in the following specification:

$$
Y_{i t}=\beta_{1} C_{i t}+\beta_{2} B U F_{i t}+\beta_{3}(C * B U F)_{i t}+\gamma^{\prime} X_{i t}+\alpha_{i}+\delta_{t}+\varepsilon_{i t}
$$

where $i$ and $t$ are the indexes for unit and time-period with corresponding $\alpha_{i}$ and $\delta_{t}$ fixed effects, and $\varepsilon_{i t}$ is unobserved component. Specifically, we focus on the analysis of portfolio choices and adjustments as an outcome of our interest $Y$ that is represented by the variable of risk density (RWATA). This indicator can be also interpreted as a strategic decision on the mix of assets in the portfolio with underlying risk characteristics. To assess the contribution and drivers of changes in portfolio, we decompose the risk density ratio and analyse separately its components such as risk-weighted assets (RWA) and total assets (TA). Similarly to previous specifications, we use the annual change in Common Equity Tier 1 capital ratio: $C_{i t}=C E T 1 R_{i t}-C E T 1 R_{i t-1}$ and a vector $X$ of control variables of bank-specific characteristics.

Following Angrist and Pischke (2009) and Frondel and Vance (2009), we estimate the marginal causal effect of $C$ on the expected value of $Y$ that is dependent on the variable $B U F$ if $\beta_{3} \neq 0$. Simultaneously we include bank control variables that could plausibly mitigate the confounding effect of bank capital requirements on the outcome $Y$ and control on time/unit invariant unobserved effects. Under the assumption of the linear functional form of unobserved component $\varepsilon_{i t} \sim$ iid $\left(0, \sigma^{2}\right)$ it can be explained as:

$$
\frac{\partial Y}{\partial C}=\beta_{1}+\beta_{3}(B U F)
$$

where the estimate of the marginal causal effect is given by:

$$
\frac{\partial^{2} Y}{\partial C \partial B U F}=\beta_{3} .
$$

Thus, our model in Eq. (8) asserts that the impact of a change in capital $C$ on the outcome of interest $Y$ depends on the value of the $B U F$ when we control on the bank-specific observable characteristics $X$ and unit/time-invariant 
effects. Under plausible assumption (see Section 3.3) that the changes in standard capital requirements (i.e. CET1 ratio) affect both treated (stress-tested) and control group identically, we consider the effect of changes in capitalization on the outcome to be constant also within the treated group.

We expect that IV BUF in interaction with changes in CET1 ratio $\left(\beta_{3}\right)$ will have a similar sign and statistically significant coefficients as the standalone CET1 ratio $\left(\beta_{1}\right)$ to confirm the evidence of the bank's responses solely stemming from the scrutiny of the regulatory stress test. In Table 4, we report the results of the specification including IV BUF (columns 1, 3 and 5) and adding the interaction terms (columns 2, 4 and 6) to visualize the process of identification of marginal effect from regulatory stress tests. The coefficients on the standalone independent variable RWATA (-0.005) and its interaction with the instrument variable buffer (-0.057) emphasize that the regulatory stress test leads to the reduction of the portfolio riskiness. It is achieved primarily by decreasing the risk-weighted assets. The coefficients (columns 3 and 4) are statistically significant and with the identical sign for standalone independent variable RWA (-0.017) and in interaction with IV BUF rises (-0.326), while the total assets remain unaffected. The coefficients of changes in CET1 ratio (in Column 5) and in interaction with IV BUF (in Column 6) are not statistically significant.

Table 4. The reaction of the stress-tested banks (treated) to the regulatory stress test rounds in 2011, 2014 and 2016

\begin{tabular}{|c|c|c|c|c|c|c|}
\hline & \multicolumn{6}{|c|}{ Dependent Variables Annual Change ( $\Delta$ in pp or \%) } \\
\hline & \multicolumn{2}{|c|}{ RWATA } & \multicolumn{2}{|c|}{ RWA } & \multicolumn{2}{|c|}{ TA } \\
\hline & $(1)$ & $(2)$ & (3) & (4) & $(5)$ & $(6)$ \\
\hline$\triangle \mathrm{CET} 1 \mathrm{R}$ & $\begin{array}{c}-0.005^{* * *} * \\
(0.002)\end{array}$ & $\begin{array}{l}-0.003 \\
(0.002)\end{array}$ & $\begin{array}{c}-0.017 * * \\
(0.008)\end{array}$ & $\begin{array}{c}-0.005 \\
(0.007)\end{array}$ & $\begin{array}{c}-0.006 \\
(0.006)\end{array}$ & $\begin{array}{c}-0.000 \\
(0.008)\end{array}$ \\
\hline BUF & $\begin{array}{c}0.014 \\
(0.062)\end{array}$ & $\begin{array}{c}0.021 \\
(0.060)\end{array}$ & $\begin{array}{c}0.562 * * \\
(0.225)\end{array}$ & $\begin{array}{c}0.616 * * * \\
(0.217)\end{array}$ & $\begin{array}{c}0.260 * * \\
(0.129)\end{array}$ & $\begin{array}{c}0.274 * * \\
(0.131)\end{array}$ \\
\hline$\triangle \mathrm{CET} 1 \mathrm{R} \times \mathrm{BUF}$ & & $\begin{array}{c}-0.057 * * \\
(0.026)\end{array}$ & & $\begin{array}{c}-0.326 * * * \\
(0.087)\end{array}$ & & $\begin{array}{c}-0.118 \\
(0.115)\end{array}$ \\
\hline Constant & $\begin{array}{l}-0.019 \\
(0.055)\end{array}$ & $\begin{array}{c}-0.024 \\
(0.052)\end{array}$ & $\begin{array}{c}0.017 \\
(0.189)\end{array}$ & $\begin{array}{c}-0.008 \\
(0.172)\end{array}$ & $\begin{array}{c}-0.011 \\
(0.153)\end{array}$ & $\begin{array}{l}-0.015 \\
(0.151)\end{array}$ \\
\hline Bank Controls & Yes & Yes & Yes & Yes & Yes & Yes \\
\hline Unit FE & Yes & Yes & Yes & Yes & Yes & Yes \\
\hline Time FE & Yes & Yes & Yes & Yes & Yes & Yes \\
\hline Observations & 362 & 362 & 362 & 362 & 362 & 362 \\
\hline R-squared & 0.141 & 0.154 & 0.190 & 0.249 & 0.074 & 0.087 \\
\hline Adjusted R2 & 0.107 & 0.117 & 0.158 & 0.217 & 0.039 & 0.049 \\
\hline
\end{tabular}


F test

0.000

0.000

0.000

0.000

0.0086

0.0099

Note: Robust standard errors in parentheses. $* * * \mathrm{p}<0.01, * * \mathrm{p}<0.05, * \mathrm{p}<0.1$

We can conclude that the inclusion of the banks into the regulatory stress tests leads to a reduction in risk-weighted assets, while seemingly not impacting the total assets. Potentially, this effect can signify the reshuffling of asset structure toward the less capital intensive areas.

\subsection{Size effects}

In this section, we investigate how the size of the banks and systemic importance affect the results of baseline model Eq. (4). To perform a check of the results on the sensitivity to the bank size, we narrowed down the sample by excluding i) the banking institutions with a status of Globally Systemically Important Banks (G-SIBs) 8 and alternatively, ii) large financial institutions with assets size more than 100 billion EUR9.

In Table 5 we present results of the regression model in Eq. (4) replicated for these two subsamples. In the sample excluding GSIBs, we observe the minor effect of heterogeneity due to the systemic important status of financial institutions. In Column (7), the coefficient (-0.047) for a treatment effect $W$ is statistically significant for the outcome variable risk-weighted assets (RWA). The size of the effect is slightly less comparing to the coefficient $(-0.052)$ in the full sample (in Table 3). Thus we can conclude that the overall results reiterate those based on the full dataset. In case, when we restrict a sample to the total assets up to 100 billion EUR, we observe a significant decline in the size of the effect of regulatory stress tests on the risk-weighted assets. In Column 3, we observe that the coefficient for the outcome variable RWA declines to (-0.009) and is less statistically significant (90\% confidence level). This indicates that the adjustments in the portfolio are more relevant for larger and systemically important institutions, while the smaller size bank units remain passive and do not adjust their portfolios in response to the scrutiny of regulatory stress tests as much as bigger banks.

Table 5. Regression results of the baseline model Eq. (4) on the subsamples

\begin{tabular}{lllllllll}
\multicolumn{3}{c}{ Banks with TA<100bln } & & \multicolumn{3}{c}{ Excluding GSIBs } \\
\hline$(1)$ & $(2)$ & $(3)$ & $(4)$
\end{tabular}

8 List of G-SIBs: Barclays, BBVA, BNP Paribas, Commerzbank, Deutsche Bank, Dexia, Goupe BPCE, Groupe Credit Agricole, HSBS, ING Bank, Nordea, Royal Bank of Scotland, Santander, Societe Generale, Standard Chartered, Unicredit.

9 EBA classifies the size of financial institution according to their assets: small (below 20bln EUR), medium (from 20 to 100bln EUR) and large (above 100bln EUR). 


\begin{tabular}{|c|c|c|c|c|c|c|c|c|}
\hline VARIABLES & $\begin{array}{c}\text { RWATA } \\
(\Delta \text { p.p })\end{array}$ & $\begin{array}{c}\text { NPL } \\
(\Delta \mathrm{p} . \mathrm{p}) \\
\end{array}$ & $\begin{array}{l}\text { RWA } \\
(\Delta \%) \\
\end{array}$ & $\begin{array}{c}\text { LOAN } \\
(\Delta \%) \\
\end{array}$ & $\begin{array}{c}\text { RWATA } \\
(\Delta \text { p.p })\end{array}$ & $\begin{array}{c}\text { NPL } \\
(\Delta \mathrm{p} . \mathrm{p}) \\
\end{array}$ & $\begin{array}{l}\text { RWA } \\
(\Delta \%) \\
\end{array}$ & $\begin{array}{c}\text { LOAN } \\
(\Delta \%) \\
\end{array}$ \\
\hline W & $\begin{array}{c}-0.000 \\
(0.013)\end{array}$ & $\begin{array}{c}0.010 \\
(0.007)\end{array}$ & $\begin{array}{l}-0.009 * \\
(0.024)\end{array}$ & $\begin{array}{c}0.019 \\
(0.043)\end{array}$ & $\begin{array}{c}-0.012 \\
(0.013)\end{array}$ & $\begin{array}{c}0.009 \\
(0.006)\end{array}$ & $\begin{array}{l}-0.047^{*} \\
(0.025)\end{array}$ & $\begin{array}{c}0.005 \\
(0.023)\end{array}$ \\
\hline$\triangle \mathrm{CET} 1 \mathrm{R}$ & $\begin{array}{c}-0.005 * * * \\
(0.002)\end{array}$ & $\begin{array}{c}-0.000 \\
(0.001)\end{array}$ & $\begin{array}{c}-0.015 * * \\
(0.006)\end{array}$ & $\begin{array}{c}-0.006 * * * \\
(0.002)\end{array}$ & $\begin{array}{c}-0.005 * * * \\
(0.001)\end{array}$ & $\begin{array}{c}-0.000 \\
(0.001)\end{array}$ & $\begin{array}{c}-0.015 * * * \\
(0.005)\end{array}$ & $\begin{array}{c}-0.006 * * \\
(0.003)\end{array}$ \\
\hline Constant & $\begin{array}{c}0.644 * * * \\
(0.232)\end{array}$ & $\begin{array}{c}-0.093 \\
(0.178)\end{array}$ & $\begin{array}{c}-0.248 \\
(0.738)\end{array}$ & $\begin{array}{c}-1.546 * * * \\
(0.467)\end{array}$ & $\begin{array}{c}0.601 \\
(0.204)\end{array}$ & $\begin{array}{l}-0.025 \\
(0.161)\end{array}$ & $\begin{array}{c}0.046 \\
(0.594)\end{array}$ & $\begin{array}{r}-1.333 * * \\
(0.637)\end{array}$ \\
\hline Unit FE & Yes & Yes & Yes & Yes & Yes & Yes & Yes & Yes \\
\hline Time FE & Yes & Yes & Yes & Yes & Yes & Yes & Yes & Yes \\
\hline Bank Controls & Yes & Yes & Yes & Yes & Yes & Yes & Yes & Yes \\
\hline Observations & 1,594 & 1,386 & 1,586 & 1,605 & 1,950 & 1,722 & 1,945 & 1,965 \\
\hline R-squared & 0.258 & 0.287 & 0.382 & 0.311 & 0.248 & 0.275 & 0.374 & 0.313 \\
\hline F-test & 0.000 & 0.000 & 0.000 & 0.000 & 0.000 & 0.000 & 0.000 & 0.000 \\
\hline $\begin{array}{l}\text { Sample } \\
\text { characteristics }\end{array}$ & $\begin{array}{l}\text { Treated } \\
\text { Control }\end{array}$ & $\begin{array}{l}=65 \text { units } \\
=298 \text { uni }\end{array}$ & $\begin{array}{l}\text { S }(58 \%) \\
\text { its }(90 \%)\end{array}$ & & $\begin{array}{l}\text { Treate } \\
\text { Contr }\end{array}$ & $\begin{aligned} \mathrm{d} & =98 \mathrm{uni} \\
\mathrm{l} & =330 \mathrm{u}\end{aligned}$ & $\begin{array}{l}\text { ts }(88 \%) \\
\text { nits }(99 \%)\end{array}$ & \\
\hline
\end{tabular}

Note: Robust standard errors in parentheses $* * * \mathrm{p}<0.01, * * \mathrm{p}<0.05, * \mathrm{p}<0.1$

We have to note that in general, the larger banks tend to have more sophisticated risk management processes and advanced methods in the calculation of risk-weighted assets e.g. advanced IRB approach that allows them to capture the riskiness of portfolio more thoroughly and present lower risk weights. Moreover, the larger and systemically important institutions have more incentives to adjustments in the portfolio, since they face the overall higher regulatory scrutiny due to their status, and not necessarily from regulatory stress tests. On the other hand, when we reduce the sample by total assets size further, the number of banks in the treated group reduces disproportionally large in comparison to the control group. The treated group becomes less representative and possibly leading to the misidentification. For example, when we restrict the sample to the banks' units below 100 billion EUR in assets, the treated group reduces almost by half (58\% of the original treated group). EBA stress test in 2011 includes many smaller banks, while the test rounds in 2016 consists of the largest financial institutions in EU including GSIBs.

\section{Robustness checks and additional analyses}

In this section, we provide additional analysis and show that our results are robust to a number of specifications, under alternative assumptions and for subsamples. First, we perform the several tests on parallel trend assumption that is underlining and important for unbiased identification of the DID estimator. Second, we perform an analysis 
of treatment effect taking into account the unobserved heterogeneity with the engagement of the structural equations.

\subsection{Tests of the parallel trends assumption}

The failure of the parallel trend assumption due to diverging trends between treated and control banks is a common threat for the identification of the generalized DID estimators (Callaway and Sant'Anna, 2019; Imai and Kim, 2019b). In the current setting, a parallel trend assumption implies that the portfolio adjustment strategies of the banks would be the same in the absence of treatment, all else being equal. In this section, we present the results of two alternative tests of the parallel trend assumption. The first test augments the model with bank-specific leads of the treatment variable to detect anticipation effects (Callaway and Sant'Anna, 2019). The second test controls for the bank-specific trends in the regression model when there is a concern that the specification is sensitive to functional form assumptions (Lee and Solon, 2011; Wolfers, 2006).

\subsubsection{Effect of anticipation and pre-trends}

In this section, we check if there are any ex-ante adjustments in portfolio attributable to the anticipation of the event of the treatment. Perhaps banking units began changing their behaviour in response to an expectation that they would be "treated" in the future. In other words, we test the extent to which the anticipated capital charge, based on the knowledge from previous regulatory tests, is incorporated into the capital planning process. The underlying assumption for an unbiased estimate of $\tau$ in Eq. (4) and Eq. (5) is that the trends in the outcomes for both control and treated groups in the absence of treatment effect are parallel.

Since the regulatory stress tests were introduced in a staggered manner as in our sample, we examine the parallel trends assumption for all outcome variables using an event study approach. Following (Callaway and Sant'Anna, 2019; He and Wang, 2017; Imai and Kim, 2019b), we introduce a stronger version of the conditional parallel trends assumption, that is supposed to hold for all periods $t$. Namely, we assess the reliability of the parallel trends assumption not only for the pre-treatment periods $e \leq t$, but also for the additional periods where $e>t$, which are post-treatment periods. The proposed testing procedure exploits more information, therefore it is able to detect a broader set of violations of the stronger conditional parallel trends condition. Specifically, we estimate the following equation: 


$$
\Delta Y_{i t}=\alpha_{i}+\delta_{t}+\sum_{k \geq-2, k \neq-1}^{k=2} W_{i t}^{k} \cdot \tau_{k}+\beta \Delta C_{i t}+\gamma^{\prime} X_{i t}+\varepsilon_{i t}
$$

where $Y_{i t}$ represents the main outcomes of interests for the bank unit $i$ in year $t$. The dummy variables $W_{i t}^{k}$ jointly represent the assignment of the event, whereby $e_{i}$ denotes a year when the bank unit $i$ became a subject to the regulatory stress tests. We define $W_{i t}^{-2}=1$ if $t-e_{i} \leq-2$ and zero otherwise; $W_{i t}^{k}=1$ if $t-e_{i}=k$ and zero otherwise, where $k=0,1$; and $W_{i t}^{2}=1$ if $t-e_{i} \geq 2$ and zero otherwise. While $\alpha_{i}$ is a unit and $\delta_{t}$ is a year fixed effect. Note that similarly to He and Wang (2017) we omit the dummy $k=-1$ in Equation (11), so that posttreatment effects are relative to the period immediately prior to the start of the regulatory stress test. The parameter of our interest $\tau_{k}$ estimates the effect of enhanced scrutiny of regulatory stress test for years following its occurrence. We include the leads in assignment dummy $W$ in the equation testing whether the treatment affects the outcomes (for up to two years) before they were a subject to regulatory stress tests. In Table 6, we report the results for several outcome metrics in columns (1-4). A test of the parallel trends assumption shows that the leads of the treatments have no substantial impact on the outcomes i.e., $\tau_{k}=0$ for $\mathrm{k} \leq-2$. However, it reveals a slight tendency toward the anticipation factor for the indicators of RWA and NPL. In Column 2 and 3, we observe the coefficients statistically significant at $90 \%$ confidence level. This is attributable to the expectation of monitoring and other initiatives e.g. Comprehensive Assessment or Asset Quality Review which are ongoing in parallel over the observed time horizon and can influence the results of the test.

Table 6. Test for the Parallel Trends Assumption

\begin{tabular}{lcccc}
\hline VARIABLES & $\begin{array}{c}(1) \\
\text { RWATA } \\
(\Delta \text { p.p. })\end{array}$ & $\begin{array}{c}(2) \\
\text { NPL } \\
(\Delta \text { p.p. })\end{array}$ & $\begin{array}{c}(3) \\
\text { RWA } \\
(\Delta \%)\end{array}$ & $\begin{array}{c}(4) \\
\text { LOAN } \\
(\Delta \%)\end{array}$ \\
\hline \multirow{2}{*}{2 years before } & & & & \\
& -0.041 & $-0.016^{*}$ & $-0.124^{*}$ & -0.026 \\
Year of event & $(0.027)$ & $(0.008)$ & $(0.072)$ & $(0.038)$ \\
1 year later & -0.012 & 0.007 & $-0.052^{* *}$ & 0.002 \\
& $(0.012)$ & $(0.006)$ & $(0.023)$ & $(0.021)$ \\
2 years later & 0.009 & -0.032 & -0.015 & -0.039 \\
& $(0.019)$ & $(0.025)$ & $(0.043)$ & $(0.038)$ \\
$\Delta$ CET1R & 0.052 & -0.003 & 0.080 & 0.001 \\
Constant & $(0.034)$ & $(0.011)$ & $(0.060)$ & $(0.043)$ \\
& $-0.005^{* * *}$ & -0.000 & $-0.015 * * *$ & $-0.006^{* *}$ \\
Bank Controls & $(0.001)$ & $(0.001)$ & $(0.005)$ & $(0.003)$ \\
& $0.599 * * *$ & -0.008 & -0.081 & $-1.415^{* *}$ \\
& $(0.175)$ & $(0.123)$ & $(0.549)$ & $(0.562)$
\end{tabular}




\begin{tabular}{lcccc} 
Unit FE & Yes & Yes & Yes & Yes \\
Time FE & Yes & Yes & Yes & Yes \\
Observations & 2,039 & 1,808 & 2,035 & 2,056 \\
R-squared & 0.265 & 0.276 & 0.392 & 0.344 \\
F test & 0.000 & 0.000 & 0.000 & 0.000 \\
\hline Robust standard errors in parentheses. $* * * \mathrm{p}<0.01, * * \mathrm{p}<0.05, * \mathrm{p}<0.1$ &
\end{tabular}

\subsubsection{Bank specific trends}

In the previous section, we applied an event study approach for testing on the factor of pre-trends when we adjust for the extrapolation of a linear trend over the pre-treatment and post-treatment periods. This approach provides valid inference only under the assumption that the underlying trend is exactly linear. In this section, we test whether the results of the specification are sensitive to the functional form assumptions. In other words, we test if there is a difference in slope between treatment and comparison groups prior to the intervention. Following (Friedberg, 1998; He and Wang, 2017; Wolfers, 2006), we incorporate a product of bank-specific trends in the baseline model in Eq. (4). Specifically, we augment the model by the product $\phi_{i} \cdot t$ and a quadratic term, $\lambda_{i} \cdot t^{2}$, where $i$ is the indicator for banks and $t$ stands for the time dimension:

$$
\Delta Y_{i t}=\alpha_{i}+\delta_{t}+\tau \cdot W_{i t}+\beta \Delta C_{i t}+\gamma^{\prime} X_{i t}+\phi_{i} \cdot t+\lambda_{i} \cdot t^{2}+\varepsilon_{i t}
$$

In Table 7, we report the results of the regression Eq. (12) which includes the unit-specific-linear trends in Columns (2, 5, 8 and 11) and additionally with unit-specific-quadratic trends in Columns (3, 6, 9 and 12). After including bank-specific trends the statistical significance of the coefficients remains unchanged for both treatment indicator $(\mathrm{W})$ and the indicator of changes in the capital $(\triangle \mathrm{CET} 1 \mathrm{R})$. Thus, the magnitude of the effect is negligible. The values of adjusted R-squared are slightly higher (from 0.097 to 0.101 ) for risk density and (from 0.128 to 0.140) for RWA since data now explain a greater portion of the variation of dependent variables. Concluding, the regression results of the augmented model indicate that the specification is not sensitive to variations in the estimation method and functional form.

Table 7. Test for the Parallel Trends Assumption

\begin{tabular}{|c|c|c|c|c|c|c|c|c|c|c|c|c|}
\hline \multirow[t]{2}{*}{ VARIABLES } & \multicolumn{3}{|c|}{ 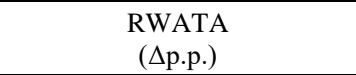 } & \multicolumn{3}{|c|}{ 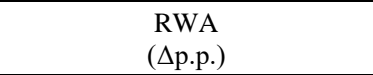 } & \multicolumn{3}{|c|}{$\begin{array}{l}\text { NPL } \\
(\Delta \%)\end{array}$} & \multicolumn{3}{|c|}{$\begin{array}{c}\text { LOAN } \\
(\Delta \%)\end{array}$} \\
\hline & (1) & (2) & (3) & (4) & (5) & (6) & (7) & $(8)$ & (9) & (10) & (11) & (12) \\
\hline $\mathrm{W}_{-}$ & $\begin{array}{l}-0.011 \\
(0.011)\end{array}$ & $\begin{array}{l}-0.009 \\
(0.011)\end{array}$ & $\begin{array}{c}-0.011 \\
(0.011)\end{array}$ & $\begin{array}{l}-0.052 * * \\
(0.021)\end{array}$ & $\begin{array}{c}-0.045^{* *} \\
(0.022)\end{array}$ & $\begin{array}{c}-0.052 * * \\
(0.022)\end{array}$ & $\begin{array}{l}0.005 \\
(0.005)\end{array}$ & $\begin{array}{c}0.009 * \\
(0.005)\end{array}$ & $\begin{array}{l}0.008 \\
(0.005)\end{array}$ & $\begin{array}{c}0.000 \\
(0.020)\end{array}$ & $\begin{array}{c}0.000 \\
(0.020)\end{array}$ & $\begin{array}{c}0.003 \\
(0.020)\end{array}$ \\
\hline
\end{tabular}




\begin{tabular}{|c|c|c|c|c|c|c|c|c|c|c|c|c|}
\hline$\triangle \mathrm{CET} 1 \mathrm{R}$ & $\begin{array}{c}-0.005 * * * \\
(0.001)\end{array}$ & $\begin{array}{c}-0.004 * * * \\
(0.001)\end{array}$ & $\begin{array}{c}-0.005^{* * *} * \\
(0.001)\end{array}$ & $\begin{array}{c}-0.015^{* * *} * \\
(0.004)\end{array}$ & $\begin{array}{l}-0.015^{* * *} * \\
(0.004)\end{array}$ & $\begin{array}{l}-0.015^{* * *} \\
(0.004)\end{array}$ & $\begin{array}{l}-0.000 \\
(0.001)\end{array}$ & $\begin{array}{l}0.000 \\
(0.001)\end{array}$ & $\begin{array}{l}-0.000 \\
(0.001)\end{array}$ & $\begin{array}{c}-0.006 * * \\
(0.002)\end{array}$ & $\begin{array}{c}-0.006 * * \\
(0.002)\end{array}$ & $\begin{array}{c}-0.006 * * \\
(0.002)\end{array}$ \\
\hline Constant & $\begin{array}{c}0.598 * * * \\
(0.157)\end{array}$ & $\begin{array}{l}0.573 * * * \\
(0.159)\end{array}$ & $\begin{array}{l}0.943 * * * \\
(0.224)\end{array}$ & $\begin{array}{l}-0.069 \\
(0.497)\end{array}$ & $\begin{array}{l}-0.222 \\
(0.491)\end{array}$ & $\begin{array}{l}1.200 * * \\
(0.602)\end{array}$ & $\begin{array}{l}-0.007 \\
(0.111)\end{array}$ & $\begin{array}{l}-0.053 \\
(0.104)\end{array}$ & $\begin{array}{l}0.068 \\
(0.179)\end{array}$ & $\begin{array}{c}-1.403^{* * *} * \\
(0.498)\end{array}$ & $\begin{array}{c}-1.403 \text { *** } \\
(0.498)\end{array}$ & $\begin{array}{c}-1.806 * * \\
(0.734)\end{array}$ \\
\hline Bank Controls & Yes & Yes & Yes & Yes & Yes & Yes & Yes & Yes & Yes & Yes & Yes & Yes \\
\hline Unit FE & Yes & Yes & Yes & Yes & Yes & Yes & Yes & Yes & Yes & Yes & Yes & Yes \\
\hline Time FE & Yes & Yes & Yes & Yes & Yes & Yes & Yes & Yes & Yes & Yes & Yes & Yes \\
\hline Bank Trends & No & Yes & Yes & No & Yes & Yes & No & Yes & Yes & No & Yes & Yes \\
\hline Unit*time & - & Yes & Yes & - & Yes & Yes & - & Yes & Yes & - & Yes & Yes \\
\hline Unit $^{*}$ time 2 & - & No & Yes & - & No & Yes & - & No & Yes & - & No & Yes \\
\hline $\mathrm{R}_{2}$ & 0.104 & 0.105 & 0.109 & 0.135 & 0.140 & 0.147 & 0.094 & 0.107 & 0.108 & 0.046 & 0.046 & 0.046 \\
\hline Adj.-R2 & 0.097 & 0.098 & 0.101 & 0.128 & 0.133 & 0.140 & 0.086 & 0.098 & 0.099 & 0.0380 & 0.0380 & 0.0381 \\
\hline F test & 0.000 & 0.000 & 0.000 & 0.000 & 0.000 & 0.000 & 0.000 & 0.000 & 0.000 & 0.000 & 0.000 & 0.000 \\
\hline N. of clusters & 382 & 382 & 382 & 385 & 385 & 385 & 348 & 348 & 348 & 381 & 381 & 381 \\
\hline Obs. & 2,039 & 2,039 & 2,039 & 2,035 & 2,035 & 2,035 & 1,808 & 1,808 & 1,808 & 2,056 & 2,056 & 2,056 \\
\hline
\end{tabular}

Robust standard errors in parentheses. $* * * \mathrm{p}<0.01, * * \mathrm{p}<0.05, * \mathrm{p}<0.1$

\subsection{Structural equations and the unobserved heterogeneity}

As a robustness check, we analyse a treatment effect by taking into account not only observable but also an unobservable element. For this purpose, we employ a system of simultaneous equations in the form of two-stage least squares (2SLS) with the IV and assigned confounders. Here our approach is to use the IV in order to enhance the external validity of regression specifications by calculating the fitted treatment effect value conditional on observable characteristics (bank-specific variables identical to all previous specifications) and considering the latent element of unobserved heterogeneity. The structural form of simultaneous equations with IV allows to control for unobserved heterogeneity and also to decrease the simultaneity bias of capital-risk relation. For the binary treatment indicator, we employ the Probit-OLS, Probit-2SLS and direct-2SLS estimators. The standard post-estimation tests for qualifying to the IV are performed.

In practice, we solve the system of structural equations by running the two regression models with observable and unobservable heterogeneous treatment effects: direct-2SLS (IV regression estimated by direct two-stage least squares), Probit-OLS (IV two-step regression estimated by Probit and OLS) and Probit-2SLS (IV regression estimated by probit and two-stage least squares)10. The procedure steps in the calculation of the structural equations can be summarized as:

10 We provide a more detailed information on the potential outcome framework including the description of IV, in Appendix Methodological Addendum 
(i) estimate the $\widehat{w}$ by regressing on IV $z$ and set of covariates $x$ (OLS) or by applying the probit and assessing the predicted probability of $\widehat{w}$ (Probit-OLS, Probit-2SLS);

(ii) estimate the treatment effect $\tau$ by regressing $y$ on $\widehat{w}$ and covariates $x$ to account for observable characteristics.

The observable characteristics $x_{i}$ are the covariates, identical to the previous specification of the baseline model in Eq. (4) in Section 4, namely: the size of the bank's assets, a level of efficiency, funding and liquidity structure, total capitalization.

Table8 reports the results from three structural models (Probit OLS, Probit 2SLS and Direct 2SLS) for four independent variables: risk density (RWATA), risk-weighted assets, realized risk and loan growth. In overall, we observe that the instrumental variable models successfully passed the majority of tests and were particularly better for the outcome variable of risk metrics: RWATA, LOAN and NPL.

Table 8. Results of the estimation of ATE, ATET and ATENT of structural equations (Probit-OLS, Probit-2SLS, Direct-2SLS) with instrumental variable

\begin{tabular}{|c|c|c|c|c|c|c|c|c|c|c|c|c|}
\hline \multicolumn{13}{|c|}{ Dependent Variables Annual Change (in pp and \%) } \\
\hline $\begin{array}{l}\text { VARIABLE } \\
\mathrm{S}\end{array}$ & $\begin{array}{c}(1) \\
\text { RWATA } \\
\text { probit- } \\
\text { ols } \\
\end{array}$ & $\begin{array}{c}(2) \\
\text { RWATA } \\
\text { probit- } \\
\text { 2sls } \\
\end{array}$ & $\begin{array}{c}(3) \\
\text { RWATA } \\
\text { direct- } \\
\text { 2sls }\end{array}$ & $\begin{array}{c}(4) \\
\text { RWA } \\
\text { probit- } \\
\text { ols } \\
\end{array}$ & $\begin{array}{c}(5) \\
\text { RWA } \\
\text { probit- } \\
2 \text { sls } \\
\end{array}$ & $\begin{array}{c}(6) \\
\text { RWA } \\
\text { direct- } \\
2 \text { sls } \\
\end{array}$ & $\begin{array}{c}(7) \\
\text { NPL } \\
\text { probit- } \\
\text { ols } \\
\end{array}$ & $\begin{array}{c}(8) \\
\text { NPL } \\
\text { probit- } \\
\text { 2sls }\end{array}$ & $\begin{array}{c}(9) \\
\text { NPL } \\
\text { direct- } \\
\text { 2sls } \\
\end{array}$ & $\begin{array}{l}(10) \\
\text { LOAN } \\
\text { probit- } \\
\text { ols } \\
\end{array}$ & $\begin{array}{l}(11) \\
\text { LOAN } \\
\text { probit- } \\
2 \text { sls } \\
\end{array}$ & $\begin{array}{c}(12) \\
\text { LOAN } \\
\text { direct- } \\
2 \text { sls } \\
\end{array}$ \\
\hline $\mathrm{W}_{-}$ & $\begin{array}{c}-0.076^{* *} \\
(0.035)\end{array}$ & $\begin{array}{c}-0.040 * * \\
(0.018)\end{array}$ & $\begin{array}{c}-0.194 * * * \\
(0.068)\end{array}$ & $\begin{array}{c}-0.375^{* * *} \\
(0.097)\end{array}$ & $\begin{array}{c}-0.203 * * * \\
(0.059)\end{array}$ & $\begin{array}{c}-0.905^{* * *} \\
(0.258)\end{array}$ & $\begin{array}{c}0.006 \\
(0.017)\end{array}$ & $\begin{array}{c}0.003 \\
(0.009)\end{array}$ & $\begin{array}{c}0.000 \\
(0.023)\end{array}$ & $\begin{array}{c}-0.162^{*} \\
(0.097)\end{array}$ & $\begin{array}{l}-0.078 \\
(0.050)\end{array}$ & $\begin{array}{l}-0.156 \\
(0.141)\end{array}$ \\
\hline _ws_Talog & & $\begin{array}{c}0.006 \\
(0.005)\end{array}$ & $\begin{array}{c}0.054 * * * \\
(0.019)\end{array}$ & & $\begin{array}{c}0.010 \\
(0.015)\end{array}$ & $\begin{array}{c}0.249 * * * \\
(0.073)\end{array}$ & & $\begin{array}{c}-0.002 \\
(0.002)\end{array}$ & $\begin{array}{c}0.000 \\
(0.007)\end{array}$ & & $\begin{array}{c}-0.005 \\
(0.014)\end{array}$ & $\begin{array}{c}0.043 \\
(0.039)\end{array}$ \\
\hline _ws_LAR & & $\begin{array}{l}-0.040 \\
(0.065)\end{array}$ & $\begin{array}{c}-0.272 * * \\
(0.109)\end{array}$ & & $\begin{array}{l}-0.162 \\
(0.199)\end{array}$ & $\begin{array}{c}-1.238^{* * *} \\
(0.413)\end{array}$ & & $\begin{array}{l}-0.030 \\
(0.032)\end{array}$ & $\begin{array}{l}-0.018 \\
(0.024)\end{array}$ & & $\begin{array}{l}-0.061 \\
(0.181)\end{array}$ & $\begin{array}{l}-0.098 \\
(0.220)\end{array}$ \\
\hline _ws_DLR & & $\begin{array}{c}0.052 \\
(0.043)\end{array}$ & $\begin{array}{c}0.347 * * * \\
(0.110)\end{array}$ & & $\begin{array}{l}-0.095 \\
(0.132)\end{array}$ & $\begin{array}{c}1.318 * * * \\
(0.420)\end{array}$ & & $\begin{array}{l}-0.012 \\
(0.023)\end{array}$ & $\begin{array}{c}0.005 \\
(0.050)\end{array}$ & & $\begin{array}{l}-0.126 \\
(0.121)\end{array}$ & $\begin{array}{c}0.086 \\
(0.216)\end{array}$ \\
\hline _ws_COST & & $\begin{array}{c}0.012 \\
(0.021)\end{array}$ & $\begin{array}{l}-0.009 \\
(0.012)\end{array}$ & & $\begin{array}{c}0.001 \\
(0.064)\end{array}$ & $\begin{array}{c}0.001 \\
(0.045)\end{array}$ & & $\begin{array}{c}0.037 * * * \\
(0.009)\end{array}$ & $\begin{array}{l}0.008 * \\
(0.004)\end{array}$ & & $\begin{array}{l}0.108 * \\
(0.059)\end{array}$ & $\begin{array}{c}0.075^{* * * *} \\
(0.026)\end{array}$ \\
\hline _ws_NIM & & $\begin{array}{l}-0.003 \\
(0.005)\end{array}$ & $\begin{array}{c}-0.032 * * * \\
(0.010)\end{array}$ & & $\begin{array}{c}0.043 * * * \\
(0.016)\end{array}$ & $\begin{array}{c}-0.107 * * * \\
(0.038)\end{array}$ & & $\begin{array}{c}0.002 \\
(0.003)\end{array}$ & $\begin{array}{l}-0.000 \\
(0.004)\end{array}$ & & $\begin{array}{l}0.027 * \\
(0.015)\end{array}$ & $\begin{array}{l}-0.017 \\
(0.022)\end{array}$ \\
\hline -ws_CAR & & $\begin{array}{l}-0.222 \\
(0.157)\end{array}$ & $\begin{array}{c}0.130 \\
(0.080)\end{array}$ & & $\begin{array}{c}-1.572 * * * \\
(0.493)\end{array}$ & $\begin{array}{c}0.842 * * * \\
(0.306)\end{array}$ & & $\begin{array}{l}-0.021 \\
(0.067)\end{array}$ & $\begin{array}{l}-0.024 \\
(0.035)\end{array}$ & & $\begin{array}{l}-0.612 \\
(0.441)\end{array}$ & $\begin{array}{c}0.045 \\
(0.169)\end{array}$ \\
\hline Controls & Yes & Yes & Yes & Yes & Yes & Yes & Yes & Yes & Yes & Yes & Yes & Yes \\
\hline Time FE & Yes & Yes & Yes & Yes & Yes & Yes & Yes & Yes & Yes & Yes & Yes & Yes \\
\hline Constant & $\begin{array}{c}0.086^{* *} \\
(0.039)\end{array}$ & $\begin{array}{l}-0.033 \\
(0.025)\end{array}$ & $\begin{array}{l}-0.031 \\
(0.021)\end{array}$ & $\begin{array}{c}0.089 \\
(0.080)\end{array}$ & $\begin{array}{c}0.076 \\
(0.087)\end{array}$ & $\begin{array}{l}0.190^{*} \\
(0.113)\end{array}$ & $\begin{array}{l}0.028^{*} \\
(0.015)\end{array}$ & $\begin{array}{c}0.029 * * \\
(0.014)\end{array}$ & $\begin{array}{c}0.025^{* *} \\
(0.012)\end{array}$ & $\begin{array}{c}0.005 \\
(0.079)\end{array}$ & $\begin{array}{c}0.026 \\
(0.068)\end{array}$ & $\begin{array}{l}0.169 * \\
(0.091)\end{array}$ \\
\hline Observations & 2,039 & 2,039 & 2,039 & 2,035 & 2,035 & 2,035 & 1,808 & 1,808 & 1,808 & 2,051 & 2,051 & 2,056 \\
\hline $\begin{array}{c}\text { Instrument } \\
\text { Variable } \\
\end{array}$ & Yes & Yes & Yes & Yes & Yes & Yes & Yes & Yes & Yes & Yes & Yes & Yes \\
\hline$\overline{\text { ATE }}$ & -0.0757 & -0.0398 & -0.194 & -0.375 & -0.203 & -0.905 & 0.0064 & 0.0026 & 0.0003 & -0.162 & -0.0778 & -0.156 \\
\hline ATET & -0.0531 & -0.0280 & -0.0952 & -0.304 & -0.183 & -0.462 & 0.0027 & -0.0017 & 0.0007 & -0.145 & -0.0890 & -0.0811 \\
\hline
\end{tabular}


Note: standard errors in parentheses $* * * \mathrm{p}<0.01,{ }^{*} \mathrm{p}<0.05,{ }^{*} \mathrm{p}<0.1$

By comparing the results of structural models reported in Table 8, the conclusion can be drawn that regulatory stress has an impact on the changes in portfolio composition and risk measured by risk density RWATA (Columns 1-3) and its component RWAs (Columns 4-6). Similarly to previous specifications, there is no impact observed for the realized risk measured by non-performing exposure (Columns 7-9), since all coefficients are not statistically significant. Assuming that the results for the outcome variable changes in RWA are not strongly distorted by the endogeneity issues, they show the major contribution to the changes in risk density. In line with previous observations, the mixed results are reported for indicator changes in loan volumes, in Columns 10-12. To summarize, all results of structural models with instrumented variable reiterate the findings from the baseline DID specifications in Eq. (4) and (5).

\section{Discussion and conclusions}

In this article, we investigated the bank's response to the enhanced regulatory scrutiny and additional capital requirements from regulatory stress testing in the EU. Using the econometric approach of event study and causal inference on the dataset of the banks subject to EBA stress testing exercises in 2011, 2014 and 2016, we find evidence of the significant and lasting impact of regulatory stress tests on the portfolio choices and investment strategies. In response to the regulatory EU-wide stress tests, we document a decrease in the riskiness of portfolios mostly attributable to the decline in risk-weighted assets. Simultaneously, we observe that the realized risk of the portfolio measured by non-performing exposure metrics remains unaffected. These findings suggest that regulatory stress tests effectively prevent risky lending by imposing a higher capital charge and correspondingly banks adjust their portfolios to the less capital intensive areas. Overall, we cannot find a negative effect on the lending activities linked to the enhanced regulatory scrutiny of regulatory stress tests. At the same time, the dynamics of changes in CET1 ratio are associated with the decline in loan volume growth in our sample for both treated and control groups.

The analysis of the heterogeneity of treatment effect in time-dynamic settings points to the lasting adjustments in the balance sheet and portfolio structures in response to the regulatory stress test framework. Over the observation 
window of 2011 to 2018, we find a strong impact on the portfolio's composition that has been distributed evenly over the three waves of regulatory stress tests rounds. We conclude that the business models and portfolio structure have been constantly adapting toward the less risky portfolios and presumably with less sensitive exposure to an economic shock. This creates concern on the incentivizing toward portfolio shifting to the less capital intensive assets. In the long run, it could be a prerequisite for systemic risks in the concentration of a certain type of assets or lead to the misguidance on the asset-risk return allocation.

The estimates of the impact of regulatory scrutiny from stress tests indicate strong heterogeneity of the effect size due to the size of financial institution. The larger and systemically important institutions behave differently from smaller counterparts in response to the regulatory policy. The evidence based on the analysis of two alternative subsamples (one excluding the GSIBs and another restricted to the banks with the size of the asset below EUR 100 billion) suggest that the magnitude of the changes in portfolio rise with the size of the assets. While the smaller size banks do not exhibit a similar pattern of response to the regulatory actions.

This study suggests that the indicated effect of the portfolio adjustment strategies might challenge the major simplification assumption i.e. the static balance sheet assumption, in the stress testing methodology that does not consider the dynamic adjustments in the balance sheet and portfolios. Similarly, the studies of alternative assumptions e.g. (Busch et al., 2017) on the example of stress-tested banks in Germany, indicate the presence of temporal dynamics in banks responses that differentiates strongly between the large and smaller banks.

Another important issue which is indirectly derived from our analysis is that the "bottom-up" approach of microprudential stress testing let the riskiness of assets be determined on the basis of the bank's internal risk models, which raises the importance of the elaborated and aligned risk model landscape. Clearly, it places an important role for the supervision of model landscape and risk governance within organizations (Stein and Wiedemann, 2018) to avoid the situation of "institutionalizing" model risk (Kupiec, 2019; Witzany, 2017b) and materially underestimate the vulnerability of banks to adverse circumstances (European Central Bank, 2019).

Drawing on our "ex-post" analysis should enable the institutions and regulators to define and calibrate new rules and fine-tune methodologies to account for the bank reactions and portfolio dynamics. From a practical point of view, this study provides a series of methodological tools that allow the evaluation of the distinct impact of the 
enhanced scrutiny and higher capital requirements on the portfolio and balance sheet adjustments in response to the regulatory actions. As a result, it facilitates a more precise assessment of the existing methodologies and thus leads to improvements in the evaluation of financial system resilience to economic shocks.

\section{References}

Abraham, S., Sun, L., 2018. Estimating Dynamic Treatment Effects in Event Studies with Heterogeneous Treatment Effects (No. 1804.05785), Papers. arXiv.org.

Acharya, V.V., Berger, A.N., Roman, R.A., 2018. Lending implications of U.S. bank stress tests: Costs or benefits? Journal of Financial Intermediation, Assessing Banking Regulation During the Obama Era 34, 58-90. https://doi.org/10.1016/j.jfi.2018.01.004

Acharya, V.V, Engle, R., Pierret, D., 2014. Testing macroprudential stress tests: The risk of regulatory risk weights. Journal of Monetary Economics, Carnegie-Rochester-NYU Conference Series on Public Policy "A Century of Money, Banking, and Financial Instability" held at the Tepper School of Business, Carnegie Mellon University on November 15-16, 2013 65, 36-53. https://doi.org/10.1016/j.jmoneco.2014.04.014

Acharya, V.V., Mehran, H., Thakor, A.V., 2015. Caught between Scylla and Charybdis? Regulating Bank Leverage When There Is Rent Seeking and Risk Shifting. Review of Corporate Finance Studies cfv006. https://doi.org/10.1093/rcfs/cfv006

Agarwal, S., Lucca, D.O., Seru, A., Trebbi, F., 2014. Inconsistent Regulators: Evidence from Banking. The Quarterly Journal of Economics 129, 889-938.

Aggarwal, R., Jacques, K.T., 2004. The impact of FDICIA and prompt corrective action on bank capital and risk: Estimates using a simultaneous equations model. Journal of Banking \& Finance 25, 1139-1160. https://doi.org/10.1016/S0378-4266(00)00125-4

Ahnert, L., Vogt, P., Vonhoff, V., Weigert, F., 2018. The Impact of Regulatory Stress Testing on Bank's Equity and CDS Performance (SSRN Scholarly Paper No. ID 3179540). Social Science Research Network, Rochester, NY.

Andersen, H., Gerdrup, K.R., Johansen, R.M., Krogh, T., 2019. A Macroprudential Stress Testing Framework (Working paper). Norges Bank.

Angrist, J.D., Krueger, A.B., 2001. Instrumental Variables and the Search for Identification: From Supply and Demand to Natural Experiments. Journal of Economic Perspectives 15, 69-85. https://doi.org/10.1257/jep.15.4.69

Angrist, J.D., Pischke, J.-S., 2009. Mostly Harmless Econometrics: An Empiricist's Companion. Princeton University Press.

Athey, S., Imbens, G.W., 2018. Design-based Analysis in Difference-In-Differences Settings with Staggered Adoption (Working Paper No. 24963). National Bureau of Economic Research. https://doi.org/10.3386/w24963

Bassett, W.F., Berrospide, J.M., 2018. The Impact of Post Stress Tests Capital on Bank Lending (No. 2018- 087), Finance and Economics Discussion Series. Board of Governors of the Federal Reserve System (US).

Berger, A.N., Bouwman, C.H.S., 2012. How Does Capital Affect Bank Performance During Financial Crises? (SSRN Scholarly Paper No. ID 1739089). Social Science Research Network, Rochester, NY.

Besanko, D., Kanatas, G., 1996. The Regulation of Bank Capital: Do Capital Standards Promote Bank Safety? Journal of Financial Intermediation 5, 160-183. https://doi.org/10.1006/jfin.1996.0009

Blossfeld, H.-P., Rohwer, G., Schneider, T., 2019. Event history analysis with Stata, 2nd ed. Routledge.

Borusyak, K., Jaravel, X., 2018. Revisiting Event Study Designs (SSRN Scholarly Paper No. ID 2826228). Social Science Research Network, Rochester, NY. https://doi.org/10.2139/ssrn.2826228 
Brambor, T., Clark, W.R., Golder, M., 2006. Understanding Interaction Models: Improving Empirical Analyses. Political Analysis 14, 63-82.

Bräuning, F., Fillat, J.L., 2019. Stress Testing Effects on Portfolio Similarities Among Large Us Banks (SSRN Scholarly Paper No. ID 3416874). Social Science Research Network, Rochester, NY.

Budnik, K.B., Balatti, M., Covi, G., Dimitrov, I., Groß, J., Hansen, I., Kleemann, M., Reichenbachas, T., Sanna, F., Sarychev, A., Siņenko, N., Volk, M., Cera, K., di Iasio, G., Giuzio, M., Mirza, H., Moccero, D., Nicoletti, G., Pancaro, C., Palligkinis, S., 2019. Macroprudential Stress Test of the Euro Area Banking System (SSRN Scholarly Paper No. ID 3414174). Social Science Research Network, Rochester, NY.

Busch, R., Drescher, C., Memmel, C., 2017. Bank stress testing under different balance sheet assumptions (No. 07/2017), Discussion Papers. Deutsche Bundesbank.

Calem, P.S., Correa, R., Lee, S.J., 2017. Prudential Policies and Their Impact on Credit in the United States (SSRN Scholarly Paper No. ID 2967129). Social Science Research Network, Rochester, NY.

Callaway, B., Sant'Anna, P.H.C., 2019. Difference-in-Differences with Multiple Time Periods (SSRN Scholarly Paper No. ID 3148250). Social Science Research Network, Rochester, NY.

Camara, B., Lepetit, L., Tarazi, A., 2013. Ex Ante Capital Position, Changes in the Different Components of Regulatory Capital and Bank Risk (No. 7), Débats économiques et financiers. Banque de France.

Campbell, T.S., Kracaw, W.A., 1980. Information Production, Market Signalling, and the Theory of Financial Intermediation. The Journal of Finance 35, 863-882. https://doi.org/10.2307/2327206

Candelon, B., Sy, A.N.R., 2015. How Did Markets React to Stress Tests? International Monetary Fund.

Carboni, M., Fiordelisi, F., Ricci, O., Lopes, F.S.S., 2017. Surprised or not surprised? The investors' reaction to the comprehensive assessment preceding the launch of the banking union. Journal of Banking \& Finance 74, 122-132. https://doi.org/10.1016/j.jbankfin.2016.11.004

Cerulli, G., 2015. Econometric Evaluation of Socio-Economic Programs: Theory and Applications, Advanced Studies in Theoretical and Applied Econometrics. Springer-Verlag, Berlin Heidelberg.

Cerulli, G., 2014. ivtreatreg: A command for fitting binary treatment models with heterogeneous response to treatment and unobservable selection. Stata Journal 14, 453-480.

Cerulli, G., Gabriele, R., Tundis, E., 2014. Identification and estimation of treatment effects in the presence of neighbourhood interactions. Louvain-la-Neuve: European Regional Science Association (ERSA).

Cohen, B., Scatigna, M., 2016. Banks and capital requirements: Channels of adjustment. Journal of Banking \& Finance 69, S56-S69.

Cortés, K., Demyanyk, Y., Li, L., Loutskina, E., Strahan, P.E., 2018. Stress Tests and Small Business Lending (Working Paper No. 24365). National Bureau of Economic Research. https://doi.org/10.3386/w24365

de Chaisemartin, C., D'Haultfœuille, X., 2018. Two-way fixed effects estimators with heterogeneous treatment effects. arXiv:1803.08807 [econ].

Diamond, D.W., 1984. Financial Intermediation and Delegated Monitoring. The Review of Economic Studies 51, 393-414. https://doi.org/10.2307/2297430

Eber, M., Minoiu, C., 2016. How Do Banks Adjust to Stricter Supervision? (SSRN Scholarly Paper No. ID 2662502). Social Science Research Network, Rochester, NY.

European Central Bank, 2019. The evolution of stress-testing in Europe [WWW Document]. The evolution of stress-testing in Europe. URL https://www.ecb.europa.eu/press/key/date/2019/html/ecb.sp190904_2 4c8236275b.en.html (accessed 9.23.19).

Flannery, M.J., 2013. Measuring Equity Capital for Stress -- Testing Large Financial Institutions (SSRN Scholarly Paper No. ID 2370104). Social Science Research Network, Rochester, NY.

Friedberg, L., 1998. Did Unilateral Divorce Raise Divorce Rates? Evidence from Panel Data. The American Economic Review 88, 608-627.

Frondel, M., Vance, C., 2009. On Marginal and Interaction Effects: The Case of Heckit and Two-Part Models (SSRN Scholarly Paper No. ID 1493156). Social Science Research Network, Rochester, NY. https://doi.org/10.2139/ssrn.1493156

Furlong, F.T., Keeley, M.C., 1991. Capital regulation and bank risk-taking: a note (reprinted from Journal of Banking and Finance). Economic Review 34-39. 
Georgescu, O.M., Gross, M., Kapp, D., Kok, C., 2017a. Do Stress Tests Matter? Evidence from the 2014 and 2016 Stress Tests (SSRN Scholarly Paper No. ID 2968952). Social Science Research Network, Rochester, NY.

Georgescu, O.M., Gross, M., Kapp, D., Kok, C., 2017b. Do Stress Tests Matter? Evidence from the 2014 and 2016 Stress Tests (SSRN Scholarly Paper No. ID 2968952). Social Science Research Network, Rochester, NY.

Glasserman, P., Tangirala, G., 2016. Are the Federal Reserve's Stress Test Results Predictable? The Journal of Alternative Investments 18, 82. https://doi.org/10.3905/jai.2016.18.4.082

Golder, S.N., 2005. Pre-electoral coalitions in comparative perspective: A test of existing hypotheses. Electoral Studies 24, 643-663. https://doi.org/10.1016/j.electstud.2005.01.007

Goldstein, I., Sapra, H., 2014. Should Banks' Stress Test Results be Disclosed? An Analysis of the Costs and Benefits. FIN 8, 1-54. https://doi.org/10.1561/0500000038

Goncharenko, R., Hledik, J., Pinto, R., 2018. The dark side of stress tests: Negative effects of information disclosure. Journal of Financial Stability 37, 49-59. https://doi.org/10.1016/j.jfs.2018.05.003

Goodman-Bacon, A., 2018. Difference-in-Differences with Variation in Treatment Timing (Working Paper No. 25018). National Bureau of Economic Research. https://doi.org/10.3386/w25018

Gropp, R., Mosk, T.C., Ongena, S., Wix, C., 2018. Bank Response to Higher Capital Requirements: Evidence from a Quasi-Natural Experiment (SSRN Scholarly Paper No. ID 2877771). Social Science Research Network, Rochester, NY.

He, G., Wang, S., 2017. Do College Graduates Serving as Village Officials Help Rural China? American Economic Journal: Applied Economics 9, 186-215. https://doi.org/10.1257/app.20160079

Imai, K., Kim, I.S., 2019a. When Should We Use Unit Fixed Effects Regression Models for Causal Inference with Longitudinal Data? American Journal of Political Science 63, 467-490. https://doi.org/10.1111/ajps.12417

Imai, K., Kim, I.S., 2019b. On the Use of Two-way Fixed Effects Regression Models for Causal Inference with Panel Data.

Imbens, G.W., 2014. Instrumental Variables: An Econometrician's Perspective. Statist. Sci. 29, 323-358. https://doi.org/10.1214/14-STS480

Imbens, G.W., Rubin, D.B., 2015. Causal Inference for Statistics, Social, and Biomedical Sciences by Guido W. Imbens, Cambridge Core - Econometrics and Mathematical Methods -.

Janda, K., Kravtsov, O., 2018. Basel III Leverage and Capital Ratio over the Economic Cycle in the Czech Republic and its Comparison with the CEE Region. European Financial and Accounting Journal 2018, 5-24. https://doi.org/10.18267/j.efaj.216

Jeitschko, T.D., Jeung, S.D., 2006. Do Well-Capitalized Banks Take More Risk? Evidence from the Korean Banking System (SSRN Scholarly Paper No. ID 929124). Social Science Research Network, Rochester, NY.

Kuc, M., Teply, P., 2015. A Comparison of Financial Performance of Czech Credit Unions and European Cooperative Banks (No. 2015/18), Working Papers IES. Charles University Prague, Faculty of Social Sciences, Institute of Economic Studies.

Kupiec, P., 2019. Policy Uncertainty, Financial Stability, and Stress Testing (SSRN Scholarly Paper No. ID 3363866). Social Science Research Network, Rochester, NY.

Lee, J.Y., Solon, G., 2011. The Fragility of Estimated Effects of Unilateral Divorce Laws on Divorce Rates (NBER Working Paper No. 16773). National Bureau of Economic Research, Inc.

Leland, H., Pyle, D.H., 1977. Informational Asymmetries, Financial Structure, and Financial Intermediation. Journal of Finance 32, 371-87.

Lindquist, K.-G., 2003. Banks' buffer capital: How important is risk? (No. 2003/11), Working Paper. Norges Bank.

Mésonnier, J.-S., Monks, A., 2014. Did the EBA Capital Exercise Cause a Credit Crunch in the Euro Area? (Working paper). Banque de France.

Petrella, G., Resti, A., 2013. Supervisors as information producers: Do stress tests reduce bank opaqueness? Journal of Banking \& Finance 37, 5406-5420. 
Pierret, D., Steri, R., 2019. Stressed Banks (SSRN Scholarly Paper No. ID 3066403). Social Science Research Network, Rochester, NY.

Plosser, M.C., Santos, J.A.C., 2018. Banks' Incentives and Inconsistent Risk Models. Rev Financ Stud 31, 2080 2112. https://doi.org/10.1093/rfs/hhy028

Roengpitya, R., Tarashev, N., Tsatsaronis, K., Villegas, A., 2017. Bank business models: popularity and performance (No. 682), BIS Working Papers. Bank for International Settlements.

Rosenbaum, P.R., Rubin, D.B., 1983. The Central Role of the Propensity Score in Observational Studies for Causal Effects. Biometrika 70, 41-55. https://doi.org/10.2307/2335942

Rubin, D.B., 2005. Causal Inference Using Potential Outcomes: Design, Modeling, Decisions. Journal of the American Statistical Association 100, 322-331. https://doi.org/10.1198/016214504000001880

Schuermann, T., 2013. Stress Testing Banks (SSRN Scholarly Paper No. ID 2041579). Social Science Research Network, Rochester, NY.

Shrieves, R.E., Dahl, D., 1992. The Relationship between Risk and Capital in Commercial Banks (SSRN Scholarly Paper No. ID 2487420). Social Science Research Network, Rochester, NY.

Stádník, B., Raudeliūnienė, J., Davidavičienė, V., 2016. Fourier Analysis for Stock Price Forecasting: Assumption and Evidence. Journal of Business Economics and Management 17, 365-380. https://doi.org/10.3846/16111699.2016.1184180

Stein, V., Wiedemann, A., 2018. Risk Governance: Basic Rationale and Tentative Findings from the German Banking Sector, in: Idowu, S.O., Sitnikov, C., Simion, D., Bocean, C.G. (Eds.), Current Issues in Corporate Social Responsibility: An International Consideration, CSR, Sustainability, Ethics \& Governance. Springer International Publishing, Cham, pp. 97-110. https://doi.org/10.1007/978-3-31970449-4_7

Sutorova, B., Teply, P., 2013. The Impact of Basel III on Lending Rates of EU Banks. Czech Journal of Economics and Finance (Finance a uver) 63, 226-243.

Teplý, P., Mejstř́ik, M., Pečená, M., 2015. Bankovnictví v teorii a praxi / Banking in Theory and Practice, e-book. Knihkupectví Karolinum.

Vozková, K., Teplý, P., 2018. Determinants of Bank Fee Income in the EU Banking Industry - Does Market Concentration Matter? Prague Economic Papers 27, 3-20. https://doi.org/10.18267/j.pep.645

White, H., 1980. A Heteroskedasticity-Consistent Covariance Matrix Estimator and a Direct Test for Heteroskedasticity. Econometrica 48, 817-838. https://doi.org/10.2307/1912934

Witzany, J., 2017a. A Bayesian Approach to Backtest Overfitting (SSRN Scholarly Paper No. ID 3002503). Social Science Research Network, Rochester, NY.

Witzany, J., 2017b. Credit Risk Management, in: Credit Risk Management: Pricing, Measurement, and Modeling. Springer International Publishing, Cham, pp. 5-18. https://doi.org/10.1007/978-3-319-49800-3_2

Wolfers, J., 2006. Did Unilateral Divorce Laws Raise Divorce Rates? A Reconciliation and New Results. American Economic Review 96, 1802-1820. https://doi.org/10.1257/aer.96.5.1802

Wooldridge, J., 2012. Introductory Econometrics: A Modern Approach, 5th ed. South-Western College Pub.

Wooldridge, J., 2010. Econometric Analysis of Cross Section and Panel Data| The MIT Press.

Zhang, D., Cai, J., Dickinson, D.G., Kutan, A.M., 2016. Non-performing loans, moral hazard and regulation of the Chinese commercial banking system. Journal of Banking \& Finance 63, 48-60. 


\section{Appendix}

\section{Table I. Definitions and sources of the variables}

This table reports summary and definitions for the variables in our analysis, and source for all the regression variables.

\begin{tabular}{lll}
\hline Variables $\quad$ Definitions & Source
\end{tabular}

\section{Dependent: Bank Risk \& Performance}

$\triangle R W A T A$

$\triangle R W A$

$\triangle N P L$

$\triangle L O A N$

Control

Variables

$\triangle C E T 1 R$

$T A$

$L A R$

$D L R$

COST

NIM

CAR

Instrumental Variable

$B U F$

Instrumental variable calculated as a measure of capital gap or surplus based on the published results of EBA stress tests
Orbis BankFocus

Orbis BankFocus

Orbis BankFocus

Orbis BankFocus

Orbis BankFocus

Orbis BankFocus

Orbis BankFocus

Orbis BankFocus

Orbis BankFocus

Orbis BankFocus

Orbis BankFocus

EBA reports / website

EBA reports / website

$W \quad$ Event treatment dummy in binary form

Bank FE Dummy variable for each of the banks unit

Time FE

Annual year dummy variables for all time periods 
Table II. Descriptive statistics of the instrumental variable "buffer" (BUF)

Distribution of the IV BUF in the entire sample

\begin{tabular}{cccll}
\hline & Percentiles & Smallest & & \\
$1 \%$ & -0.0736 & -0.12989 & & \\
$5 \%$ & -0.0162 & -0.12145 & & 560 \\
$10 \%$ & 0.00019 & -0.1142 & Obs & 560 \\
$25 \%$ & 0.0199 & -0.1106 & Sum of Wgt. & \\
& & & & 0.0449 \\
$50 \%$ & 0.03873 & & Mean & 0.0598 \\
& & Largest & Std. Dev. & \\
$75 \%$ & 0.05967 & 0.311297 & & 0.0036 \\
$90 \%$ & 0.08563 & 0.490185 & Variance & 4.0883 \\
$95 \%$ & 0.11781 & 0.555669 & Skewness & 34.407 \\
$99 \%$ & 0.29901 & 0.618207 & Kurtosis & \\
\hline
\end{tabular}

Descriptive statistics of the IV BUF per year

\begin{tabular}{|cccccc|}
\hline Year & mean & std & min & $\mathbf{m a x}$ & $\mathbf{N}$ \\
------- & -------- & -------- & ------ & -------- \\
2011 & 0.029293 & 0.02393 & -0.03823 & 0.085795 & 70 \\
2012 & 0.021668 & 0.029784 & -0.06912 & 0.086418 & 70 \\
2013 & & & & & 0 \\
2014 & 0.061232 & 0.072268 & -0.1106 & 0.618207 & 110 \\
2015 & 0.049635 & 0.069575 & -0.12145 & 0.555669 & 110 \\
2016 & 0.039324 & 0.068394 & -0.12989 & 0.490185 & 110 \\
2017 & 0.059431 & 0.048625 & -0.02099 & 0.311297 & 51 \\
2018 & 0.051473 & 0.051473 & -0.07728 & 0.299014 & 51 \\
& & & & & \\
\hline
\end{tabular}


Table III. Key facts about the EU-wide regulatory stress test and our sample

This Table reports the key information about the stress test and sample of the banks we used for our study.

\begin{tabular}{|c|c|c|c|c|c|}
\hline & 2010 & 2011 & 2014 & 2016 & 2018 \\
\hline Announcement Date & $18 / 06 / 2010$ & $13 / 01 / 2011$ & $31 / 01 / 2014$ & $05 / 11 / 2015$ & $31 / 01 / 2018$ \\
\hline Release Date & 26/07/2010 & $18 / 07 / 2011$ & $27 / 10 / 2014$ & $01 / 08 / 2016$ & $02 / 11 / 2018$ \\
\hline Competent authority & CEBS & EBA & EBA & EBA & EBA \\
\hline $\begin{array}{l}\text { \# banks tested } \\
\text { (of which in our sample) }\end{array}$ & 91 & 90 & 123 & 51 & 49 \\
\hline & - & (70) & (110) & (51) & - \\
\hline \multirow[t]{2}{*}{$\begin{array}{l}\text { \# banks failed } \\
\text { (of which in sample) }\end{array}$} & 7 & 8 & 24 & - & - \\
\hline & - & (4) & (22) & - & - \\
\hline $\begin{array}{l}\text { As } \% \text { of total EU banking } \\
\text { assets (incl. Norway, the } \\
\text { UK) }\end{array}$ & $65 \%$ & $60 \%$ & $70 \%$ & $70 \%$ & $70 \%$ \\
\hline $\begin{array}{l}\text { EBA sample selection } \\
\text { criteria (according to the } \\
\text { methodology notes of EU- } \\
\text { wide stress tests)* }\end{array}$ & $\begin{array}{l}\text { Top national } \\
\text { ranking; } \\
\text { at least } 50 \% \\
\text { of assets on } \\
\text { country level } \\
\text { incl. largest } \\
\text { subsidiaries; }\end{array}$ & $\begin{array}{l}\text { Top national } \\
\text { ranking; } \\
\text { at least } \\
50 \% \text { of } \\
\text { assets on } \\
\text { the country } \\
\text { level; } \\
\text { highest level } \\
\text { of } \\
\text { consolidation }\end{array}$ & $\begin{array}{l}\text { Top national } \\
\text { ranking; } \\
\text { at least } 50 \% \\
\text { of assets on } \\
\text { the country } \\
\text { level; } \\
\text { highest level of } \\
\text { consolidation }\end{array}$ & $\begin{array}{l}\text { Min. EUR } 30 \text { bn. } \\
\text { in assets; } \\
\text { highest level of } \\
\text { consolidation }\end{array}$ & $\begin{array}{l}\text { Min. EUR } 30 \\
\text { bn. in assets; } \\
\text { highest level } \\
\text { of } \\
\text { consolidation }\end{array}$ \\
\hline $\begin{array}{l}\text { Two scenarios (baseline and } \\
\text { adverse) over the time } \\
\text { horizon }\end{array}$ & 2 years & 2 years & 3 years & 3 years & 3 years \\
\hline $\begin{array}{l}\text { Hurdle rate** (adverse } \\
\text { scenario) }\end{array}$ & $\begin{array}{l}6 \% \text { Core Tier } 1 \\
\text { ratio }\end{array}$ & $\begin{array}{l}5 \% \text { CET1 } \\
\text { ratio }\end{array}$ & $\begin{array}{l}5.5 \% \text { CET } 1 \\
\text { ratio }\end{array}$ & $\begin{array}{l}\text { No explicit } \\
\text { hurdle rate }\end{array}$ & $\begin{array}{l}\text { No explicit } \\
\text { hurdle rate }\end{array}$ \\
\hline
\end{tabular}

* EU-wide stress test methodology notes.

** The table shows the key hurdle rates for banks to pass in adverse scenario. All data is taken from the official stress test reports available on the EBA website. For the purpose of calculation of the buffer, we applied regulatory hurdle rate $5.5 \%$ also for the stress test round in 2016. 
Table IV. List of treated and control banks

Table IV lists all banks in treated and control groups with corresponding geographies. The treated group below consists of all banks participating in three rounds of regulatory stress test conducted by EBA in 2011, 2014 and 2016. The control group lists the banks that never participated in any of the EU-wide regulatory stress test (i.e. banks which participated in regulatory stress tests conducted in 2010 and 2018 are also not included here).

\begin{tabular}{|c|c|c|c|c|c|}
\hline \multicolumn{3}{|c|}{ Treated Group } & \multicolumn{3}{|c|}{ Control Group } \\
\hline $\begin{array}{l}\text { Bank } \\
\text { Focus } \\
\text { Code }\end{array}$ & EBA ST 2011 & Country & $\begin{array}{l}\text { Bank } \\
\text { Focus } \\
\text { Code }\end{array}$ & & Country \\
\hline 46146 & ERSTE GROUP BANK AG & AT & 44015 & ALLGEMEINE SPARKASSE OBEROSTERREICH BANK AG & AT \\
\hline 40494 & RAIFFEISEN BANK INTERNATIONAL AG & AT & 44133 & BANK GUTMANN AG & AT \\
\hline 19621 & VOLKSBANK WIEN AG & AT & 45107 & BKS BANK AG & AT \\
\hline 45621 & DEXIA SA & $\mathrm{BE}$ & 46403 & HYPO NOE LANDESBANK FUR NIEDEROSTERREICH UND WIEN & AT \\
\hline 48888 & KBC GROEP NV/ KBC GROUPE SA-KBC GROUP & $\mathrm{BE}$ & 47752 & HYPO VORARLBERG BANK AG & AT \\
\hline 30823 & BANK OF CYPRUS PUBLIC COMPANY LIMITED & CY & 33785 & HYPO-BANK BURGENLAND AKTIENGESELLSCHAFT & AT \\
\hline 13109 & BAYERISCHE LANDESBANK & $\mathrm{DE}$ & 45365 & KAERNTNER SPARKASSE & AT \\
\hline 13190 & COMMERZBANK AG & $\mathrm{DE}$ & 46744 & LANDES-HYPOTHEKENBANK TIROL & AT \\
\hline 13229 & DEKABANK DEUTSCHE GIROZENTRALE & $\mathrm{DE}$ & 44316 & OBERBANK AG & AT \\
\hline 13216 & DEUTSCHE BANK AG & $\mathrm{DE}$ & 43945 & OBEROSTERREICHISCHE LANDESBANK & AT \\
\hline 17881 & DZ BANK AG-DEUTSCHE ZENTRAL- & $\mathrm{DE}$ & 44750 & OESTERREICHISCHE KONTROLLBANK AG & AT \\
\hline 47734 & LANDESBANK BADEN-WUERTTEMBERG & $\mathrm{DE}$ & 43946 & RAIFFEISENLANDESBANK NIEDEROSTERREICH-WIEN AG & AT \\
\hline 14104 & LANDESBANK BERLIN AG (LBB) & $\mathrm{DE}$ & 34513 & RAIFFEISENLANDESBANK OBEROSTERREICH AG & AT \\
\hline 13584 & NORDDEUTSCHE LANDESBANK GIROZENTRALE & DE & 43947 & RAIFFEISEN-LANDESBANK STEIERMARK AG & AT \\
\hline 43554 & NYKREDIT BANK A/S & DK & 43890 & STEIERMARKISCHE BANK UND SPARKASSEN AG & AT \\
\hline 10629 & SYDBANK A/S & DK & 37108 & VOLKSBANK VORARLBERG E.GEN. & AT \\
\hline 22628 & BANCO BILBAO VIZCAYA ARGENTARIA SA-BBVA & ES & 28761 & VOLKSBANKEN VERBUND (COMBINED) & AT \\
\hline 23370 & BANCO DE SABADELL SA & ES & 32068 & VOLKSKREDITBANK AG & AT \\
\hline MAN & BANCO POPULAR ESPANOL SA & ES & MAN & AXA BANK BELGIUM & $\mathrm{BE}$ \\
\hline 47560 & BANCO SANTANDER SA & ES & 45237 & BANK J. VAN BREDA EN CO NV & $\mathrm{BE}$ \\
\hline 22713 & BANKINTER SA & ES & 10020 & BANK OF BARODA & $\mathrm{BE}$ \\
\hline 11965 & BFA TENEDORA DE ACCIONES SAU & ES & 12239 & BANK OF NEW YORK MELLON SA/NV & $\mathrm{BE}$ \\
\hline 11963 & CAIXABANK & ES & 10093 & BANQUE CPH & $\mathrm{BE}$ \\
\hline 22804 & CAJA DE AHORROS Y MONTE DE PIEDAD DE & ES & 43165 & BANQUE DEGROOF PETERCAM SA & $\mathrm{BE}$ \\
\hline 22770 & COLONYA, CAIXA D'ESTALVIS DE POLLENSA & ES & 10113 & CRELAN SA & $\mathrm{BE}$ \\
\hline 51538 & CRITERIA CAIXA & ES & 43982 & EUROCLEAR SA/NV & $\mathrm{BE}$ \\
\hline 13996 & IBERCAJA BANCO SA & ES & 58849 & FINANCIERE DE TUBIZE SA & $\mathrm{BE}$ \\
\hline 12682 & LIBERBANK SA & ES & 44573 & INVESTAR SA & $\mathrm{BE}$ \\
\hline 51613 & UNICAJA BANCO SA & ES & 52011 & SOCIÉTÉ FÉDÉRALE DE PARTICIPATIONS ET & $\mathrm{BE}$ \\
\hline 31978 & OP FINANCIAL GROUP (COMBINED) & FI & 41665 & ALPHA BANK CYPRUS LIMITED & CY \\
\hline 10931 & BNP PARIBAS SA & FR & 48127 & RCB BANK LTD & CY \\
\hline 10708 & BPCE GROUP & FR & 12125 & B. METZLER SEEL. SOHN \& CO. HOLDING & $\mathrm{DE}$ \\
\hline 41109 & ALPHA BANK AE & GR & 13124 & BERLINER VOLKSBANK EG & $\mathrm{DE}$ \\
\hline 49514 & EUROBANK ERGASIAS SA & GR & 43869 & COMDIRECT BANK AG & $\mathrm{DE}$ \\
\hline 44317 & PIRAEUS BANK SA & GR & 15469 & DEUTSCHE KREDITBANK AG (DKB) & $\mathrm{DE}$ \\
\hline 44850 & OTP BANK PLC & HU & 13105 & DEUTSCHE PFANDBRIEFBANK AG & $\mathrm{DE}$ \\
\hline 20103 & ALLIED IRISH BANKS PLC & IE & MAN & DEUTSCHE POSTBANK AG & $\mathrm{DE}$ \\
\hline 20112 & BANK OF IRELAND & IE & 13240 & DVB BANK SE & $\mathrm{DE}$ \\
\hline 48505 & PERMANENT TSB PLC & IE & 52725 & ERWERBSGESELLSCHAFT DER S- FINANZGRUPPE MBH \& CO. & $\mathrm{DE}$ \\
\hline 18508 & BANCA IMI SPA & IT & 40583 & GLS GEMEINSCHAFTSBANK EG & $\mathrm{DE}$ \\
\hline 21413 & BANCA MONTE DEI PASCHI DI SIENA SPA & IT & 28814 & GRENKE AG & $\mathrm{DE}$ \\
\hline 57953 & BANCO BPM SPA & IT & 46604 & HAUCK \& AUFHAUSER PRIVATBANKIERS & $\mathrm{DE}$ \\
\hline 46616 & INTESA SANPAOLO & IT & 13973 & HSBC TRINKAUS \& BURKHARDT AG & $\mathrm{DE}$ \\
\hline 47295 & UNICREDIT SPA & IT & 23470 & INVESTITIONSBANK BERLIN & $\mathrm{DE}$ \\
\hline 16185 & UNIONE DI BANCHE ITALIANE SPA-UBI BANCA & IT & 15365 & INVESTITIONSBANK DES LANDES BRANDENBURG & $\mathrm{DE}$ \\
\hline 22057 & BANQUE ET CAISSE D'EPARGNE DE L'ETAT & LU & 13328 & KFW BANKENGRUPPE & $\mathrm{DE}$ \\
\hline 27933 & BANK OF VALLETTA PLC & MT & 19898 & M.M. WARBURG \& CO GRUPPE GMBH & $\mathrm{DE}$ \\
\hline 12060 & ABN AMRO GROUP N.V. & NL & 43376 & MITTELBRANDENBURGISCHE SPARKASSE IN POTSDAM & $\mathrm{DE}$ \\
\hline 22317 & COOPERATIEVE RABOBANK U.A. & NL & 15668 & MLP SE & $\mathrm{DE}$ \\
\hline 22324 & DE VOLKSBANK N.V. & NL & 23549 & ODDO BHF AKTIENGESELLSCHAFT & $\mathrm{DE}$ \\
\hline 22304 & ING GROEP NV & NL & 40606 & PROCREDIT HOLDING AG \& CO. KGAA & $\mathrm{DE}$ \\
\hline 48594 & DNB ASA & NO & 40258 & SACHSEN-FINANZGRUPPE & $\mathrm{DE}$ \\
\hline 45638 & BANCO BPI SA & PT & 14192 & SPARDA-BANK BADEN-WURTTEMBERG EG & $\mathrm{DE}$ \\
\hline 22541 & BANCO COMERCIAL PORTUGUES, SA & PT & 13866 & STADTSPARKASSE DUSSELDORF & $\mathrm{DE}$ \\
\hline 22529 & CAIXA GERAL DE DEPOSITOS & PT & 41456 & TOYOTA KREDITBANK GMBH & $\mathrm{DE}$ \\
\hline 52267 & NOVO BANCO & PT & 48232 & VOLKSBANK STRAUBING EG & $\mathrm{DE}$ \\
\hline 47155 & NORDEA BANK AB (PUBL) & SE & 14088 & VOLKSWAGEN BANK GMBH & $\mathrm{DE}$ \\
\hline 33297 & SKANDINAVISKA ENSKILDA BANKEN AB & SE & 48944 & VR PLUS ALTMARK-WENDLAND & $\mathrm{DE}$ \\
\hline 30723 & SVENSKA HANDELSBANKEN AB & SE & 40899 & ALM. BRAND A/S & DK \\
\hline 31268 & SWEDBANK AB & SE & 43629 & ARBEJDERNES LANDSBANK A/S & DK \\
\hline 31186 & NOVA KREDITNA BANKA MARIBOR D.D. & SI & 10389 & BANKNORDIK P/F & $\mathrm{DK}$ \\
\hline
\end{tabular}




\begin{tabular}{|c|c|}
\hline Code & \\
\hline 96069 & BAWAG GROUP AG \\
\hline 46146 & ERSTE GROUP BANK AG \\
\hline 40494 & RAIFFEISEN BANK INTERNATIONAL AG \\
\hline 19621 & VOLKSBANK WIEN AG \\
\hline 10006 & ARGENTA SPAARBANK \\
\hline 41465 & AXA BANK EUROPE SA/NV \\
\hline 48939 & BELFIUS BANQUE SA/NV \\
\hline 45621 & DEXIA SA \\
\hline 48888 & KBC GROEP NV/ KBC GROUPE SA-KBC GROUP \\
\hline 30823 & BANK OF CYPRUS PUBLIC COMPANY LIMITED \\
\hline 32584 & CYPRUS TURKISH COOPERATIVE CENTRAL BANK \\
\hline 31583 & HELLENIC BANK PUBLIC COMPANY LIMITED \\
\hline 13222 & AAREAL BANK AG \\
\hline 43573 & OESTERREICHISCHE ARZTE \& APOTHEKER BANK AG \\
\hline 13109 & BAYERISCHE LANDESBANK \\
\hline 13190 & COMMERZBANK AG \\
\hline 13229 & DEKABANK DEUTSCHE GIROZENTRALE \\
\hline 13216 & DEUTSCHE BANK AG \\
\hline 17881 & DZ BANK AG-DEUTSCHE ZENTRAL- \\
\hline 13289 & HASPA FINANZHOLDING \\
\hline 13319 & IKB DEUTSCHE INDUSTRIEBANK AG \\
\hline 27782 & KFW IPEX-BANK GMBH \\
\hline 47734 & LANDESBANK BADEN-WUERTTEMBERG \\
\hline 14104 & LANDESBANK BERLIN AG (LBB) \\
\hline 13306 & LANDESBANK HESSEN-THÜRINGEN GIROZENTRALE \\
\hline 48901 & LANDESKREDITBANK BADEN-WUERTTEMBERG - \\
\hline 13568 & MÜNCHENER HYPOTHEKENBANK EG \\
\hline 13584 & NORDDEUTSCHE LANDESBANK GIROZENTRALE \\
\hline 19856 & NRW.BANK \\
\hline 43859 & LANDWIRTSCHAFTLICHE RENTENBANK \\
\hline 16116 & VOLKSWAGEN FINANCIAL SERVICES AG \\
\hline 18830 & WÜSTENROT \& WÜRTTEMBERGISCHE AG \\
\hline 13101 & WÜSTENROT BAUSPARKASSE AG \\
\hline 10607 & DANSKE BANK A/S \\
\hline 10609 & JYSKE BANK A/S \\
\hline 43554 & NYKREDIT BANK A/S \\
\hline 10629 & SYDBANK A/S \\
\hline 97916 & ABANCA HOLDING FINANCIERO SA \\
\hline 22628 & BANCO BILBAO VIZCAYA ARGENTARIA SA-BBVA \\
\hline 23370 & BANCO DE SABADELL SA \\
\hline MAN & BANCO POPULAR ESPANOL SA \\
\hline 47560 & BANCO SANTANDER SA \\
\hline 22713 & BANKINTER SA \\
\hline 11965 & BFA TENEDORA DE ACCIONES SAU \\
\hline 51538 & CRITERIA CAIXA \\
\hline 13996 & IBERCAJA BANCO SA \\
\hline 14205 & KUTXABANK SA \\
\hline 12682 & LIBERBANK SA \\
\hline 31978 & OP FINANCIAL GROUP (COMBINED) \\
\hline 10931 & BNP PARIBAS SA \\
\hline 10708 & BPCE GROUP \\
\hline 12990 & BPIFRANCE FINANCEMENT SA \\
\hline 11948 & CREDIT AGRICOLE \\
\hline 39826 & CREDIT MUTUEL (COMBINED - IFRS) \\
\hline 29070 & LA BANQUE POSTALE \\
\hline 12953 & RCI BANQUE SA \\
\hline 11150 & SOCIÉTÉ GÉNÉRALE SA \\
\hline 41109 & ALPHA BANK AE \\
\hline 49514 & EUROBANK ERGASIAS SA \\
\hline 44317 & PIRAEUS BANK SA \\
\hline 44850 & OTP BANK PLC \\
\hline 20103 & ALLIED IRISH BANKS PLC \\
\hline 20112 & BANK OF IRELAND \\
\hline 48505 & PERMANENT TSB PLC \\
\hline 21498 & BANCA CARIGE SPA \\
\hline 18508 & BANCA IMI SPA \\
\hline 21413 & BANCA MONTE DEI PASCHI DI SIENA SPA \\
\hline 41128 & BANCA PICCOLO CREDITO VALTELLINESE-CREDITO \\
\hline 45798 & BANCA POPOLARE DI SONDRIO SOCIETA \\
\hline 57953 & BANCO BPM SPA \\
\hline 42468 & BPER BANCA S.P.A. \\
\hline 45740 & CREDITO EMILIANO SPA-CREDEM \\
\hline 21362 & ICCREA BANCA SPA - ISTITUTO CENTR \\
\hline
\end{tabular}

AT

10358 DANSKE ANDELSKASSERS BANK A/S DK

41161 DEN JYSKE SPAREKASSE

17477 DLR KREDIT A/S

12843 FINANSIEL STABILITET A/S

0393 FROES SPAREKASSE

44927 FYNSKE BANK A/S

43538 MIDDELFART SPAREKASSE

45291 NORDFYNS BANK A/S

42608 REALKREDIT DANMARK A/S

10612 SPAR NORD BANK

AT 41393 SPAREKASSEN SJALLAND-FYN A/S

AT 43631 SPAREKASSEN THY

AT 10267 SPAREKASSEN VENDSYSSEL

BE 52911 ANDBANK ESPANA, S.A.

BE 45465 ARESBANK SA

BE 23322 BANCA MARCH SA

BE 45469 BANCO CAIXA GERAL SA

BE 45161 BANCO COOPERATIVO ESPANOL

CY 23283 BANCO MEDIOLANUM SA

CY 22651 BANKIA, SA

CY 44555 BANKOA SA

DE 44911 CAIXA DE CREDIT DELS ENGINYERS S. COOP DE CREDIT

23740 CAJA RURAL DEL SUR, S. COOP DE CREDITO.

$\begin{array}{ll}23740 & \text { CAJA RURAL DEL } \\ 50007 & \text { CECABANK SA }\end{array}$

51586 LABORAL KUTXA

12701 RENTA 4 BANCO, S.A

17616 WIZINK BANK SA

27671 AKTIA BANK PLC

34811 ALANDSBANKEN ABP

18582 EVLI BANK PLC

18786 FINNVERA PLC

11830 HELSINKI OP BANK PLC

18618 MUNICIPALITY FINANCE PLC

51777 OMA SAASTOPANKKI

97726 POHJOIS-KARJALAN OSUUSPANKKI

54518 POP PANKKI

11296 SP MORTGAGE BANK PLC

52632 S-PANKKI OY

97728 THE SAVINGS BANKS GROUP (COMBINED)

58245 TURUN SEUDUN OSUUSPANKKI

11915 AGENCE FRANCAISE DE DEVELOPPEMENT

10856 AMUNDI SA

11146 BANQUE FEDERATIVE DU CREDIT MUTUEL

12805 BANQUE SOCREDO

10216 CAISSE D'EPARGNE CEPAC

11655 CAISSE D'EPARGNE ET DE PREVOYANCE AQUITAINE POITOU-

11652 CAISSE D'EPARGNE ET DE PREVOYANCE D'ALSACE

41657 CAISSE D'EPARGNE ET DE PREVOYANCE D'AUVERGNE ET DU

11656 CAISSE D'EPARGNE ET DE PREVOYANCE DE BOURGOGNE

12811 CAISSE D'EPARGNE ET DE PREVOYANCE DE LOIRE-DROME-

11678 CAISSE D'EPARGNE ET DE PREVOYANCE DE MIDI-PYRENEES

18566 CAISSE D'EPARGNE ET DE PREVOYANCE ILE-DE-FRANCE SA

19792 CAISSE D'EPARGNE ET DE PREVOYANCE LOIRE-CENTRE

27319 CAISSE REGIONALE DE CREDIT AGRICOLE MUTUEL ALSACE

44274 CAISSE REGIONALE DE CREDIT AGRICOLE MUTUEL

12985 CAISSE REGIONALE DE CREDIT AGRICOLE MUTUEL BRIE

42339 CAISSE REGIONALE DE CREDIT AGRICOLE MUTUEL DE LA

10738 CAISSE REGIONALE DE CREDIT AGRICOLE MUTUEL DE PARIS

27697 CAISSE REGIONALE DE CREDIT AGRICOLE MUTUEL DU NORD

17713 CAISSE REGIONALE DE CREDIT AGRICOLE MUTUEL LOIRE

46444 CAISSE REGIONALE DE CREDIT AGRICOLE MUTUEL NORD

45061 CAISSE REGIONALE DE CREDIT AGRICOLE MUTUEL

38635 CAISSE REGIONALE DE CREDIT AGRICOLE MUTUEL

43962 CAISSE REGIONALE DE CREDIT AGRICOLE MUTUEL SUD

43522 CAISSE REGIONALE DE CREDIT AGRICOLE MUTUEL

11030 CAISSE REGIONALE DE CREDIT AGRICOLE MUTUEL VAL DE

11093 COMPAGNIE FINANCIÈRE LAZARD FRÈRES SAS

43541 CRÉDIT COOPÉRATIF

11039 CREDIT DU NORD SA

10685 CREDIT FONCIER DE FRANCE SA

17451 CRÉDIT IMMOBILIER DE FRANCE DÉVELOPPEMENT SA-CIFD

10713 CRÉDIT INDUSTRIEL ET COMMERCIAL SA - CIC

46060 CREDIT MUTUEL ARKEA SA

47059 EXANE SA

59984 FINANCIERE MONCEY

11050 LE CREDIT LYONNAIS (LCL) SA

45333 NATIXIS SA

47729 ODDO BHF SCA

10791 ONEY BANK

10816 OPEL BANK

11147 PSA BANQUE FRANCE

27859 ROTHSCHILD \& CO
DK

DK

DK

DK

DK

DK

DK

DK

DK

DK

ES

ES

ES

ES

ES

ES

ES

ES

ES

ES

FI

I

I

I

FR

FR

FR

FR

FR

FR

FR

FR
FR

FR

FR

FR

FR

FR

FR

FR

FR

FR

FR

FR

FR

FR

FR

FR

FR

FR

FR

FR

FR

FR

FR

FR

FR

FR
FR 


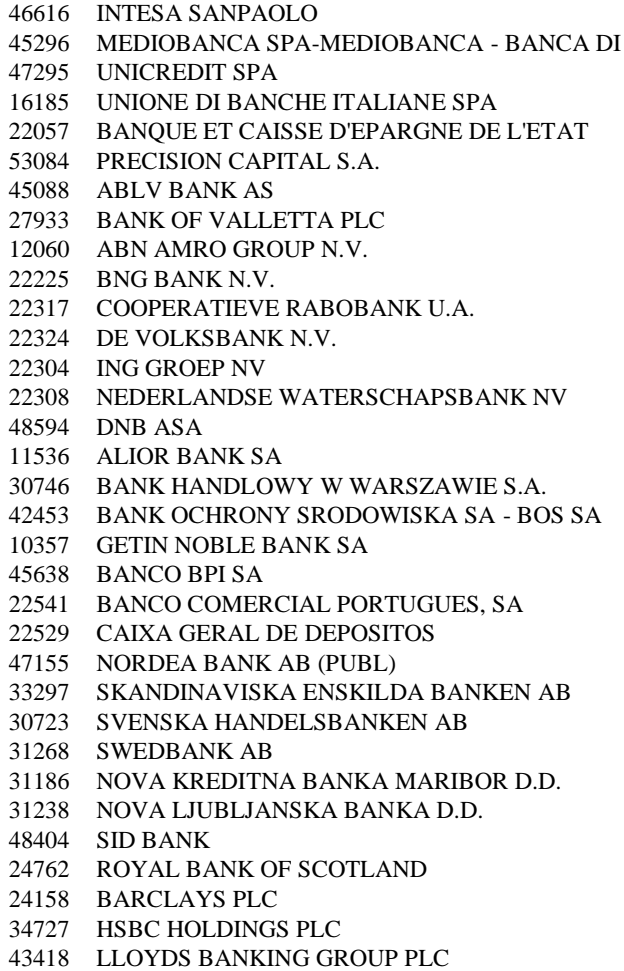

\section{EBA ST 2016}

\begin{tabular}{ll} 
Code & \\
\hline 46146 & ERSTE GROUP BANK AG \\
40494 & RAIFFEISEN BANK INTERNATIONAL AG \\
48939 & BELFIUS BANQUE SA/NV \\
48888 & KBC GROEP NV/ KBC GROUPE SA-KBC GROUP \\
13109 & BAYERISCHE LANDESBANK \\
13190 & COMMERZBANK AG \\
13229 & DEKABANK DEUTSCHE GIROZENTRALE \\
13216 & DEUTSCHE BANK AG \\
47734 & LANDESBANK BADEN-WUERTTEMBERG \\
13306 & LANDESBANK HESSEN-THÜRINGEN GIROZENTRALE \\
13584 & NORDDEUTSCHE LANDESBANK GIROZENTRALE \\
19856 & NRW.BANK \\
16116 & VOLKSWAGEN FINANCIAL SERVICES AG \\
10607 & DANSKE BANK A/S \\
10609 & JYSKE BANK A/S \\
43554 & NYKREDIT BANK A/S \\
22628 & BANCO BILBAO VIZCAYA ARGENTARIA SA-BBVA \\
23370 & BANCO DE SABADELL SA \\
MAN & BANCO POPULAR ESPANOL SA \\
47560 & BANCO SANTANDER SA \\
11965 & BFA TENEDORA DE ACCIONES SAU \\
51538 & CRITERIA CAIXA \\
31978 & OP FINANCIAL GROUP (COMBINED) \\
10931 & BNP PARIBAS SA \\
10708 & BPCE GROUP \\
11948 & CREDIT AGRICOLE \\
39826 & CREDIT MUTUEL (COMBINED - IFRS) \\
29070 & LA BANQUE POSTALE \\
11150 & SOCIÉTÉ GEENERALE SA \\
44850 & OTP BANK PLC \\
20103 & ALLIED IRISH BANKS PLC \\
20112 & BANK OF IRELAND \\
18508 & BANCA IMI SPA \\
21413 & BANCA MONTE DEI PASCHI DI SIENA SPA \\
57953 & BANCO BPM SPA \\
46616 & INTESA SANPAOLO \\
47295 & UNICREDIT SPA \\
16185 & UNIONE DI BANCHE ITALIANE SPA \\
12060 & ABN AMRO GROUP N.V. \\
22225 & BNG BANK N.V. \\
22317 & COOPERATIEVE RABOBANK U.A. \\
22304 & ING GROEP NV \\
48594 & DNB ASA \\
47155 & NORDEA BANK AB (PUBL)
\end{tabular}

19165 VIEL \& COMPAGNIE SA

20006 ATTICA BANK SA

MAN BANK OF HUNGARIAN SAVINGS COOPERATIVES LIMITED

37332 CIB BANK LTD

43243 HUNGARIAN EXPORT-IMPORT BANK PRIVATE LTD

33965 K\&H BANK ZRT

42058 MFB HUNGARIAN DEVELOPMENT BANK PRIVATE LIMITED

44318 MKB BANK ZRT

35179 TAKAREK KERESKEDELMI BANK ZRT

22598 AIB MORTGAGE BANK

52140 DELL BANK INTERNATIONAL LIMITED

20160 ULSTER BANK IRELAND DAC

48747 AGOS DUCATO SPA

21477 ALLIANZ BANK FINANCIAL ADVISORS S.P.A.

46698 BANCA AGRICOLA POPOLARE DI RAGUSA SCARL

49857 BANCA CENTROPADANA - CREDITO COOPERATIVO SCRL

46699 BANCA DI BOLOGNA - CREDITO COOPERATIVO

48418 BANCA DI CREDITO COOPERATIVO DI ALBA, LANGHE, ROERO

39690 BANCA FARMAFACTORING SPA

16150 BANCA FINNAT EURAMERICA SPA

18555 BANCA IFIS SPA

46983 BANCA MEDIOLANUM SPA

26795 BANCA NAZIONALE DEL LAVORO SPA

48114 BANCA POPOLARE DI BARI SOC. COOP.P.A

18959 BANCA POPOLARE ETICA - SOCIETA COOPERATIVA PER

45822 BANCA POPOLARE PUGLIESE

45282 BANCA SELLA HOLDING SPA

15438 BANCA SISTEMA SPA

21474 BANCO DI SARDEGNA SPA

20498 CASSA DI RISPARMIO DI ASTI SPA

20489 CASSA DI RISPARMIO DI BOLZANO SPA

19134 CASSA PADANA BANCA DI CREDITO COOPERATIVO SOCIETA

59162 CREDITO COOPERATIVO ROMAGNOLO BCC DI CESENA E

16186 FCA BANK SPA

41670 FIDEURAM-INTESA SANPAOLO PRIVATE BANKING SPA

23712 IBL ISTITUTO BANCARIO DEL LAVORO SPA

18977 INVEST BANCA SPA

MEDIOBANCA SPA

20393 SANFELICE 1893 BANCA POPOLARE SOCIETA COOPERATIVA

97007 SIA SPA

45298 AB SEB BANKAS

38058 LUMINOR BANK AB LT

38681 SIAULIU BANKAS

22028 BANQUE DEGROOF PETERCAM LUXEMBOURG SA

11572 BANQUE HAVILLAND SA

22036 BANQUE INTERNATIONALE A LUXEMBOURG SA

22033 BGL BNP PARIBAS

10416 BOA GROUP

22164 KBL EUROPEAN PRIVATE BANKERS SA

15158 QUILVEST SA

12215 AS CITADELE BANKA

44200 RIETUMU BANK GROUP

46622 SEB BANKA AS

45119 SWEDBANK AS

12559 BNF BANK PLC

44193 FIMBANK PLC

41260 HSBC BANK MALTA PLC

56486 MDB GROUP LIMITED

44089 ACHMEA BANK NV

52622 ADYEN N.V

46674 AEGON BANK NY

22241 CITCO BANK NEDERLAND NV

44090 CREDIT EUROPE BANK N.V.

97920 DE VOLKSHOLDING B.V.

MAN DELTA LLOYD BANK NV

40053 DEMIR-HALK BANK (NEDERLAND) N.V

44178 INSINGERGILISSEN BANKIERS N.V.

22292 KAS BANK NV

46570 LEASEPLAN CORPORATION NV

22222 MUFG BANK (EUROPE) NV

50931 NATIONALE-NEDERLANDEN BANK NV

22265 NIBC BANK NV

52159 PROPERTIZE B.V

41778 TRIODOS BANK NV

22273 VAN LANSCHOT KEMPEN NV

2198 ASKIM \& SPYDEBERG SPAREBANK

27371 AURSKOG SPAREBANK

34239 BN BANK ASA

MAN FANA SPAREBANK

38925 GJENSIDIGE BANK ASA

47017 HELGELAND SPAREBANK

26327 HOELAND OG SETSKOG SPAREBANK

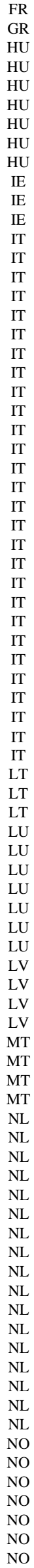


33297 SKANDINAVISKA ENSKILDA BANKEN AB

30723 SVENSKA HANDELSBANKEN AB

31268 SWEDBANK AB

24762 ROYAL BANK OF SCOTLAND

24158 BARCLAYS PLC

34727 HSBC HOLDINGS PLC

43418 LLOYDS BANKING GROUP PLC 


\begin{tabular}{|ll}
24661 & NEWBURY BUILDING SOCIETY \\
24683 & NEWCASTLE BUILDING SOCIETY \\
13782 & ONESAVINGS BANK PLC \\
42605 & PARAGON BANKING GROUP PLC \\
24725 & PRINCIPALITY BUILDING SOCIETY \\
24970 & PROGRESSIVE BUILDING SOCIETY LIMITED \\
23887 & PROVIDENT FINANCIAL PLC \\
24789 & SCHRODERS PLC \\
54758 & SHAWBROOK GROUP PLC \\
24816 & SKIPTON BUILDING SOCIETY \\
48533 & STANDARD CHARTERED BANK \\
59218 & TBC BANK GROUP PLC \\
27296 & TESCO PERSONAL FINANCE GROUP LIMITED \\
12410 & TESCO PERSONAL FINANCE PLC \\
97925 & THE CO-OPERATIVE BANK HOLDINGS LIMITED \\
12998 & VIRGIN MONEY HOLDINGS (UK) PLC \\
24491 & VTB CAPITAL PLC \\
47940 & WEATHERBYS BANK LIMITED \\
24936 & WEST BROMWICH BUILDING SOCIETY \\
24361 & WYELANDS BANK PLC \\
25036 & YORKSHIRE BUILDING SOCIETY
\end{tabular}




\section{Methodological Addendum}

\section{A. Potential outcome framework and evaluation of treatment effect (Cerulli, 2015 and Rubin, 2005)}

The following methodology describes the potential outcome framework that we employ for assessment of the heterogeneous treatment effect with instrumental variable. It can be formulated in the form of the equation: $y=$ $y_{0}+w\left(y_{1}-y_{0}\right)$, where $y$ denotes a potential outcome and $w$ is a linear probability function for propensity to be selected into the treatment. According to (Wooldridge, 2010, Ch.21) we can write the observed outcome equation $y$ as:

$$
y=\mu_{0}+\left(\mu_{1}-\mu_{0}\right) w+v_{0}+w\left(v_{1}-v_{0}\right)
$$

where $\mu_{g}=E\left(y_{g}\right)$ and $v_{g}=v_{g}-\mu_{0}, g=0,1$. If the conditional mean assumption (Imbens, 2014; Rosenbaum and Rubin, 1983) does not hold then we solve it by applying IV. The appropriate IV $z$ has to satisfy the exclusion restriction criteria. If this is a case then we can assert that: $E\left(v_{0} \mid \boldsymbol{x}, z\right)=E\left(v_{0} \mid \boldsymbol{x}\right)=g(\boldsymbol{x})=\boldsymbol{x} \boldsymbol{\beta}$ which means that $E\left(v_{0} \mid x, z\right) \neq 0$. It leads to the regression model having an error term with zero unconditional mean of this type:

$$
y=\mu_{0}+\tau w+x \beta_{0}+u_{0}
$$

where $\tau=\tau_{a t e}$ and $u_{0}=v_{0}-E\left(v_{0} \mid \boldsymbol{x}, z\right)$. All these conditions bring us the system of structural equations:

$$
\begin{aligned}
& y_{i}=\mu_{0}+w_{i} \tau+\boldsymbol{x}_{\boldsymbol{i}} \boldsymbol{\beta}+u_{0 i}, \\
& \widehat{w}_{i}=\eta+\boldsymbol{q}_{i} \boldsymbol{\delta}+\varepsilon_{i}, \\
& w_{i}=\left\{\begin{array}{lll}
1 & \text { if } \widehat{w}_{i} \geq 0 \\
0 & \text { if } \widehat{w}_{i}<0
\end{array}\right. \\
& \boldsymbol{q}_{\boldsymbol{i}}=\left(x_{i}, z_{i}\right),
\end{aligned}
$$

From the Law of Iterated Expectations, the average treatment effect (ATE), average treatment effect on treated (ATET) and average treatment effect on non-treated (ATENT) can be estimated as:

$$
\begin{aligned}
& \tau_{A T E}=\hat{\alpha}_{I V} \\
& \tau_{A T E}(x)=\hat{\alpha}_{I V}+(\boldsymbol{x}-\overline{\boldsymbol{x}}) \hat{\beta}_{I V} \\
& \tau_{A T E T}=\hat{\alpha}_{I V}+\frac{1}{\sum_{i=1}^{N} w_{i}} \sum_{i=0}^{N} w_{i}(\boldsymbol{x}-\overline{\boldsymbol{x}}) \hat{\beta}_{I V} \\
& \tau_{A T E T}(x)=\left\{\hat{\alpha}_{I V}+(\boldsymbol{x}-\overline{\boldsymbol{x}}) \hat{\beta}_{I V}\right\}_{(w=1)} \\
& \tau_{A T E N T}=\hat{\alpha}_{I V}+\frac{1}{\sum_{i=1}^{N} w_{i}} \sum_{i=0}^{N}\left(1-w_{i}\right)(\boldsymbol{x}-\overline{\boldsymbol{x}}) \hat{\beta}_{I V} \\
& \tau_{A T E N T}(x)=\left\{\hat{\alpha}_{I V}+(\boldsymbol{x}-\overline{\boldsymbol{x}}) \hat{\beta}_{I V}\right\}_{(w=0)}
\end{aligned}
$$


The average treatment effects can be consistently estimated under the Stable Unit Treatment Value Assumption (SUTVA) (Imbens, 2014; Imbens and Rubin, 2015), meaning that the potential outcome observation on one unit does not affect the particular assignment of treatments to the other units.

\section{B. Instrumental Variable}

The instrumental variable approach with the engagement of two simultaneous equations (two-stage least-square) can potentially provide a better estimation if the proper instrument variable qualifies for it. The application of instrumental variable approach requires the availability of some variable $(z)$, which we refer to as instrumental variable (IV) or instrument, that satisfies the following properties (Angrist and Krueger, 2001; Angrist and Pischke, 2009; Wooldridge, 2012):

(i) instrument $z$ has to directly correlate with the treatment $w$;

(ii) instrument $z$ has no direct effect on outcome $y$ only through the treatment indicator $w$;

(iii) instrument $z$ is independent of unmeasured confounders $u$ given the measured covariates $x$.

The qualifying of these properties commonly refer to "exclusion restriction" criteria (Imbens, 2014). The IV approach allows us to identify the causal effect of $w$ on $y$ by estimating the portion of variation in the outcome $y$ associated with the treatment $w$ that is attributable to the exogenous instrument variables $z$. Since, the regulatory stress tests, in essence, represent the hypothetical capital that is available in situation of the economic adverse conditions, it is rational to link the instrument variable to the changes in actual capital. Therefore, we define the IV for a unit $i$ as

$$
z_{i}=(\Delta C E T 1 R * B U F)_{i}
$$

where $\triangle C E T 1 R$ denotes an annual change in CET1 ratio, and BUF is a measure variable (see Section 4.1 ). The measure BUF that is indicating the gap or surplus of stressed capital serves as an indicator of the strength of regulatory scrutiny effect on the banks. Referring to the logic behind calculations of the IV $z$ (technical description provided in Section 3.3) it is reasonable to assume, first of all, that it is associated directly with treatment effect $w$, and second, it is exogenous by nature. Noting that the assigned scenarios are set on the discretion of EBA, and assuming that they are not influenced anyhow by the banks itself, we can consider them as exogenously imposed on the banking institutions. We perform also a set of standard tests to confirm the exogenous qualities and hence the suitability for instrumental variable.

The second assumption asserts that the instrument $z$ has no direct impact on outcome $y$ that is the change in risk behaviour, only through treatment indicator $w$. By set-up, the IV captures the size of hypothetical capital available according to the results of regulatory stress test by considering the adverse economic scenario. It can be viewed as an indicator of the size of impact from regulatory scrutiny. If the value of $z$ is very small, its effect (through the treatment indicator) on outcome $y$ is negligible, but if the value of $z$ is large enough it can have stronger effect 
and correspondingly larger implications (Georgescu et al., 2017; Goldstein and Sapra, 2014; Goncharenko et al., 2018).

The IV and specifications were tested on the assumptions associated with a valid instrument as proposed in studies (Angrist and Pischke, 2009; Wooldridge, 2012, 2010). First, we used a first-stage F-test to determine if there was evidence of weak instrument problems. Using the F-test criteria for the 2SLS specifications with various outcome variables, we were able to reject the null hypothesis of a weak instrument in all cases. We also employed a test on the over-identifying restrictions that is the specification test of Sargan-Hansen with J-statistics. In all three instances, the test confirms that the equations are exactly identified and we do not reject the joint null hypothesis that the instrumental variable is a valid instrument. Finally, we conducted a test to determine whether the treatment variable is endogenous (Durbin-Wu-Hausman's chi-sq test and Wu-Hausman's F-test)11. In two of three models, we were able to reject the null hypothesis that the treatment variable was exogenous at the $10 \%$ significance level or lower, and in most of the remaining models, we had few cases only with the outcome variable changes in RWA (that is the denominator of the CET1R ratio).

11 Since "ivtreatreg" STATA routine (Cerulli, 2014) does not provide post-estimation test option, we employed "ivreg2" command to re-estimate and run post-estimation tests. The results of the tests are summarized above and in details available upon request. 